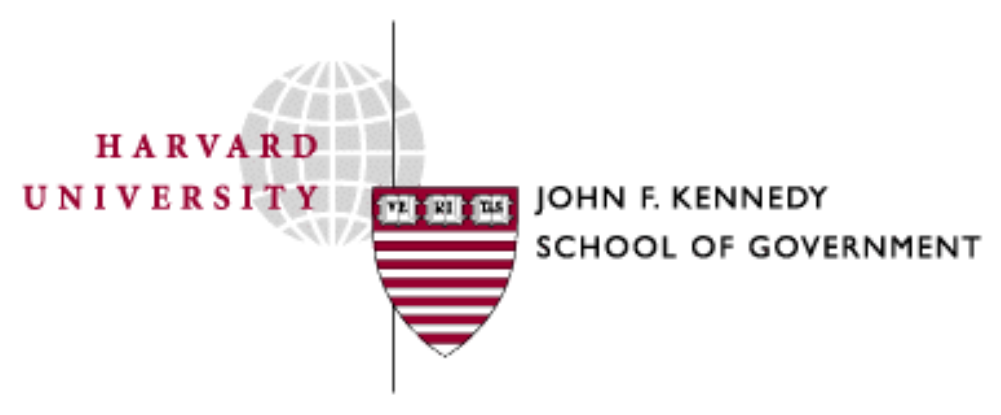

Faculty Research Working Papers Series

\author{
Precaution Against Terrorism \\ Jessica Stern \\ John F. Kennedy School of Government, Harvard University \\ Jonathan B. Wiener \\ Law School, Nicholas School \& Sanford Institute, Duke University
}

May 2006

RWP06-019

This paper can be downloaded without charge from:

http://ksgnotes1.harvard.edu/Research/wpaper.nsf/rwp/RWP06-019

or

The Social Science Research Network:

http://ssrn.com/abstract=902373

The views expressed in the KSG Faculty Research Working Paper Series are those of the author(s) and do not necessarily reflect those of the John F. Kennedy School of Government or Harvard University. Copyright belongs to the author(s). Papers may be downloaded for personal use only. 


\title{
Precaution Against Terrorism
}

\author{
Jessica Stern \\ Kennedy School of Government, Harvard University \\ Jonathan B. Wiener \\ Law School, Nicholas School \& Sanford Institute, Duke University; \\ University Fellow, Resources for the Future (RFF); \\ Visiting Professor, EHESS and CIRED, Paris, 2005-06
}

Forthcoming in Journal of Risk Research

Address correspondence to Jonathan Wiener

WIENER@law.duke.edu 
The authors are grateful for helpful comments on prior drafts to Paul Bracken, Peter Feaver, Peter Jutro, Alexsandra Lloyd, Ragnar Lofstedt, David Schanzer, Anthony Wiener, participants at the Fourth Transatlantic Dialogue on Precaution held at Duke University in September 2004, and to participants at the National Intelligence Council conference held at the Yale Club in New York in September 2005; and to Duke University students Zia Cromer (J.D. 2006) and Greg Andeck (M.E.M. 2005) and to Harvard University student Nancy Yang (BA 2009) for excellent research assistance. A version of this article also appears as a chapter in Paul Bracken, David Gordon and Ian Bremmer, eds., Managing Strategic Surprise: Lessons from Risk Management \& Risk Assessment (Cambridge Univerisity Press, 2006).

\begin{abstract}
Stunned by the terrorist attacks of September 11, 2001, the Bush administration adopted a new National Security Strategy in September 2002. The UK government took a similar stance. This new strategy calls for anticipatory attacks against potential enemies with uncertain capacities and intentions, even before their threat is imminent. Rather than wait for evidence of weapons of mass destruction, it shifts the burden of proof, obliging "rogue" states to show that they do not harbor weapons of mass destruction or terrorist cells, or else face the possibility of attack. This new strategy amounts to the adoption of the Precautionary Principle against the risk of terrorism. We offer two main conclusions about precaution against terrorism. First, any action taken to reduce a target risk always poses the introduction of countervailing risks. Moreover, a precautionary approach to terrorism is likely to entail larger, more expensive interventions, so the expected opportunity costs are likely to be higher. While considering worst-case scenarios is important for the development of sound policy, taking action based only on worst-case thinking can introduce unforeseen dangers and costs. We argue that a better approach to managing risk involves an assessment of the full portfolio of risks - those reduced by the proposed intervention, as well as those increased. We argue that decision makers developing counterterrorism measures need mechanisms to ensure that sensible risk analysis precedes precautionary actions. Such a mechanism currently exists to review and improve or reject proposed precautionary measures against health and environmental risks, but not, so far, for counterterrorism and national security policies. We urge the creation of such a review mechanism.
\end{abstract}


Terrorism poses a serious risk to health, safety and the environment. Using conventional methods such as bombs or aircraft, terrorism can cause dozens to thousands of human fatalities, spread toxic plumes of smoke, and trigger widespread fear and restrictions on civil liberties. Using weapons of mass destruction (WMD) - chemical, biological or nuclear weapons terrorism could inflict much greater harm, perhaps millions of deaths and irreparable ecological devastation. Managing the risk of terrorism has become the paramount concern of many governments. Yet the sources of terrorism are highly uncertain, very difficult to assess and manage, and intent on evading preventive measures.

Governments have many options for managing threats to national security. After several decades of pursuing deterrence and containment against the Soviet Union, the US won the Cold War, only to be stunned by the terrorist attacks of September 11, 2001. Concerned that deterrence and containment would not succeed against non-state actors willing to commit suicide attacks, and loath to repeat the mistake of 9/11 (perhaps next time with WMD), the Bush administration adopted a new National Security Strategy in September 2002. ${ }^{1}$ The UK government took a similar stance. This new strategy calls for anticipatory attacks against potential enemies with uncertain capacities and intentions, even before their threat is imminent. Rather than wait for evidence of WMD, it shifts the burden of proof, obliging "rogue" states to show that they do not harbor WMD or terrorist cells, or else face the possibility of attack. It invites international cooperation but does not oblige unilateral action to wait for UN authorization.

This new strategy amounts to the adoption of the Precautionary Principle against the risk of terrorism. The Precautionary Principle is familiar to students of risk analysis and policy. ${ }^{2}$ In various formulations in numerous international treaties and declarations on health and environmental risks, the Precautionary Principle holds that uncertainty is no excuse for inaction against serious or irreversible risks, that absence of evidence of risk is not evidence of absence of risk, and that rather than waiting for evidence of harm to be demonstrated before acting, the burden of proof should be shifted to require sponsors of a risky product or activity to demonstrate that it is safe or else be subject to regulatory restriction or ban. ${ }^{3}$ For example, the Rio Declaration in 1992 proclaimed:

"Where there are threats of serious or irreversible damage, lack of full scientific certainty shall not be used as a reason for postponing cost-effective measures to prevent environmental degradation."4

And the European Environment Agency advised in January 2002:

"Forestalling disasters usually requires acting before there is strong proof of harm.”5

Although the US government has often criticized the Precautionary Principle when applied to risks such as beef hormones, genetically modified foods and climate change, the Bush administration has made precisely the precautionary case for its decisions to undertake anticipatory counterterrorism measures, from domestic security to detaining prisoners to the use of military force in Afghanistan and then in Iraq. The new National Security Strategy states: 
"We cannot let our enemies strike first ... [but must take] anticipatory action to defend ourselves, even if uncertainty remains as to the time and place of the enemy's attack. To forestall or prevent such hostile acts by our adversaries, the United States, will, if necessary, act preemptively. ... America will act against such emerging threats before they are fully formed. ... The greater the threat, the greater is the risk of inaction and the more compelling the case for taking anticipatory action to defend ourselves, even if uncertainty remains as to the time and place of the enemy’s attack." 6

Similarly, in justifying the war in Iraq, the UK government highlighted the threat of surprise attack with WMD, famously mentioning that Iraqi forces could deploy WMD within 45 minutes. $^{7}$

National-security analysts tend to use their own specialized language to describe strategies for managing risk. They use terms such as deterrence, pre-emption and prevention, while analysts assessing threats to the environment use terms such as control, prevention and precaution. But a strategy of prevention in regard to national security is precisely analogous to a strategy of precaution in regard to threats to health and environment. The political right tends to favor a precautionary approach in national-security affairs, while the left tends to oppose it; whereas in the areas of health and environment, the politics are reversed: The left tends to favor precaution, while the right opposes it. Perhaps for this reason, the argument we make in this paper is likely to make all sides uncomfortable.

The application of the Precautionary Principle to counterterrorism is important for us to study because it helps to lay bare some of the pros and cons of the principle, irrespective of the type of hazard or political orientation, and thereby move toward a more moderate, less ideological approach that considers consequences rather than labels. Instead of those on the political left categorically favoring precaution in the health and environmental arena but opposing it in the national security arena, and those on the political right taking the opposite categorical view, each side should see that the merits of precaution depend on the consequences of each proposed action rather than the categorical label. The left should see the potential drawbacks of precaution against health and environmental risks, and the potential case for precaution against terrorism; and the right should see the potential drawbacks of precaution in the Iraq war, and the potential case for precaution in the health and environmental arena. Assessing the application of precaution across the political spectrum can foster a more open-minded and merits-based evaluation of specific policies.

This article draws on the tools and lessons of risk analysis to analyze the new national security strategy as a strategy of precaution. First, we show the close relationship between the new strategy and the Precautionary Principle. Second, we compare the distinction between "preemptive" war and "preventive" war to the similar but differently labeled distinction in risk regulation. Third, we examine the reasons for the shift to the precautionary strategy, including strategic needs, risk assessments via intelligence estimates of WMD held by rogue states or terrorists, and the psychology of availability and dread. Finally, we explore how risk analysis can help evaluate counterterrorism measures by developing a framework for a full portfolio analysis of the multiple consequences of precaution against terrorism and its alternatives. The choice to take precautionary action confronts conflicting potential errors. Not acting may neglect a real 
risk (i.e., a false negative). Acting may prove unnecessary or misguided if the risk was unfounded or its true cause was elsewhere (i.e., a false positive). In general, policies designed to reduce the probability of false negatives, such as a potentially catastrophic surprise attack, increase the probability of false positives, such as a needless war with attendant loss of life. Moreover, precautionary action may induce new countervailing risks (or yield ancillary benefits). ${ }^{8}$ At the same time, we observe that the case of counterterrorism can provide a lesson for risk analysts: the need to anticipate and address subsequent strategic moves taken by terrorists to evade initial counterterrorism measures. In the last part, we argue that the shift of national security strategy to precaution requires a new institutional mechanism to undertake the systematic application of full portfolio risk analysis to proposed counterterrorism measures. Consistent with the longstanding system of review of health and environmental measures, we propose the creation of an institutional mechanism for full portfolio analysis of counterterrorism measures via expert review in a White House office (and in a counterpart office in other national governments or the UN Security Council).

We offer two main conclusions about precaution against terrorism. First, it is best to be precautionary about the Precautionary Principle. A precautionary approach to terrorism is likely to entail larger, more expensive interventions, so the expected opportunity costs are likely to be higher. Moreover, any action taken to reduce a target risk always poses the introduction of countervailing risks. While considering worst-case scenarios is important for the development of sound policy, taking action based only on worst-case thinking can introduce unforeseen dangers and costs. ${ }^{9}$ We argue that a better approach to managing risk involves an assessment of the full portfolio of risks - those reduced by the proposed intervention, as well as those increased.

Second, decision makers developing counterterrorism measures (including the US government, other national governments, and the UN Security Council) need mechanisms to ensure that sensible risk analysis precedes precautionary actions. Our own analysis of the consequences of precaution against terrorism indicates that ex ante analyses have been seriously incomplete. Such a mechanism currently exists to review and improve or reject proposed precautionary measures against health and environmental risks, as seen in the White House review of regulatory impact analyses, addressing benefits and costs, required by Presidential Executive Order (and similar functions in other countries). However, such a mechanism appears to be absent or underdeveloped for counterterrorism and national security policies. We urge the creation of such a review mechanism.

\section{The strategic shift to precaution}

In general, the degree of precaution can be measured in terms of timing and stringency. The sooner such measures are adopted (anticipating earlier, but with greater uncertainty, the future manifestation of the risk), and the more stringently they attempt to control the risk, the more "precautionary" such measures are. ${ }^{10}$

The Precautionary Principle takes several forms, ${ }^{11}$ with a basic formulation providing that scientific uncertainty is no excuse for inaction against serious or irreversible risks. ${ }^{12}$ The Precautionary Principle is particularly aimed at overcoming the burden of proving that a risk is 
real or imminent, and authorizing protective government action even when the risk is quite uncertain but could turn out to be very harmful. It is intended to enable and impel governments to address more risks that may be false negatives (problems initially but erroneously thought to be absent or small that later turn out to be real and serious) and to be less hesitant about regulating those that turn out to be false positives (problems initially but erroneously thought to be serious that later turn out to be absent or small). ${ }^{13}$ The Precautionary Principle is especially concerned that false negatives may be catastrophes, such as global climate change or widespread toxic pollution, and that waiting for proof will mean waiting until it is too late to avert catastrophe. Strong versions of the Precautionary Principle hold that the burden of proof should be shifted so that rather than the burden falling on governments to show that an activity is unduly risky before taking policy action, the burden instead falls on those subject to the policy to show that their activities are not unduly risky.

\section{$\underline{\text { Parallel claims of precaution }}$}

Many counterterrorism measures fit squarely into the logic of the Precautionary Principle. They often intervene in anticipation of possible but highly uncertain risks of future terrorist acts. Counterterrorism frequently operates on the basis of incomplete, even sketchy, evidence or hints of planning by secretive, shadowy groups whose true intentions, capacities, members, locations and weaponry are unknown. Counterterrorism often responds to worst-case scenarios of potential attackers' motivations and capabilities. Counterterrorism measures can be quite stringent, including: incarceration of suspects (sometimes for years with no charges filed); internment of ethnic minorities feared to harbor terrorists, e.g., Japanese-Americans during World War Two; surveillance of private citizens; assassinations of terrorist leaders; destruction of the homes of terrorists' relatives; and outright large-scale warfare. Compared to the precautionary policies adopted to regulate food safety or environmental pollution (such as product bans and costly regulations), these counterterrorism measures are far more aggressive, against equally or more uncertain sources of risk, posing roughly equal or even greater prospects of harm.

The shift to precaution in the new National Security Strategy is not unprecedented, because the US had taken selective precautionary military and covert actions in the past, but the wholesale adoption of precautionary action as the official strategy - coupled with the demonstrated will to launch precautionary wars to topple foreign governments - is quite striking. The basic approach favored during the Cold War was containment and deterrence. Containment, crystallized by George Kennan in a 1947 article in Foreign Affairs, is a policy of curtailing the spread of the adversary's sphere of influence without necessarily attempting to roll it back. Kennan understood that the Soviet system harbored the seeds of its own destruction, and that the patient application of counter-pressure against Russia's expansionist tendencies, combined with a policy of exploiting tensions within the Communist world, would be as effective in the long term, and far less dangerous than outright aggression. Deterrence involves dissuading unacceptable actions by the adversary by threatening to impose unacceptably high costs in retaliation. The US and NATO strategies during the Cold War relied heavily on deterrence, at the strategic nuclear level and also on lower rungs of the escalation ladder, to dissuade Communist countries from launching conventional attacks into Western Europe or a first strike with nuclear weapons. 
The end of the Cold War and the rise of non-state threats to international security made deterrence a less effective option. Non-state actors with no base of operations are harder to deter militarily because it is unclear whom to threaten with massive retaliation, and where. Suicide bombers, in particular, cannot be deterred with military means because they do not fear death. (Still, there may be other things they fear, such as a damaged reputation or inability to enter heaven, which decision-makers might try to exploit.) If such terrorists join forces with "rogue" states equipped with WMD - as the Bush administration feared - the result could be catastrophic. A better approach for protecting Americans in the $21^{\text {st }}$ century, the Bush administration argued, was preventive war: destroying the adversaries' weapons even if there is little or no evidence that an attack is imminent. President George W. Bush put the issue in stark terms: "Facing clear evidence of peril, we cannot wait for the final proof, the smoking gun that could come in the form of a mushroom cloud."14

In September 2002, the Bush administration announced a new doctrine of anticipatory selfdefense, which advocated using military force to prevent potential attacks by rogue states and terrorists. "We cannot let our enemies strike first," the doctrine said, but must take "anticipatory action to defend ourselves, even if uncertainty remains as to the time and place of the enemy's attack. To forestall or prevent such hostile acts by our adversaries, the United States, will, if necessary, act preemptively. ... America will act against such emerging threats before they are fully formed. ... The greater the threat, the greater is the risk of inaction and the more compelling the case for taking anticipatory action to defend ourselves, even if uncertainty remains as to the time and place of the enemy's attack."15 The approach of "taking anticipatory action," before "threats are fully formed" was justified, the president argued, because waiting for evidence or proof could result in catastrophe. If the worst possible outcome were to transpire for example, if terrorists were to detonate a nuclear weapon or spread a plague, thousands or millions of innocent US civilians could be killed.

The language used by the Bush administration to justify anticipatory war, and the war in Iraq in particular, is strikingly similar to language used by proponents of precaution in other areas. For example, compare the following two statements, the first by President Bush in 2002, the second by the EU’s Environment Commissioner Margot Wallstrom, both from 2002.

"If we wait for threats to fully materialize, we will have waited too long.",16

"If you smell smoke, you don’t wait until your house is burning down before you tackle the cause."17

Likewise nongovernmental advocates of the Precautionary Principle say:

"Sometimes if we wait for proof it is too late. ... If we always wait for scientific certainty, people may suffer and die, and damage to the natural world may be irreversible."18

And former US Vice President Al Gore has written regarding global warming: 
"We need to act now on the basis of what we know. ... The insistence on complete certainty about the full details of global warming - the most serious threat that we have ever faced - is actually an effort to avoid facing the awful, uncomfortable truth: that we must act boldly, decisively, comprehensively, and quickly, even before we know every last detail about the crisis.”19

These justifications for precaution are virtually verbatim the same justifications given by President Bush and UK Prime Minister Tony Blair for preventive intervention to fight the uncertain risk of terrorism. "President Bush argued that the risk of WMD was great enough to warrant an attack, without absolute proof that Iraq was hiding such weapons. That's the PP [Precautionary Principle], American style,” according to Samuel Loewenberg writing in the New York Times. ${ }^{20}$

Moreover, the Bush administration also adopted the precautionary strategy of shifting the burden of proof. The traditional basis for the use of force in national self-defense is that the country has been attacked, or that an attack is imminent. The burden of proof is on the country exercising preemptive self-defense to show that its enemy is about to attack. There was no evidence that Iraq was about to attack the US or the UK, but there were intelligence claims that Iraq had capabilities - WMD - to attack without warning and with catastrophic consequences. Still, during the 1990s the burden of proof was on the US and the UN Security Council to find evidence of Iraqi WMD before authorizing further sanctions or intervention. Hence the team of UN inspectors searched for WMD in Iraq (until evicted by former Iraqi President Saddam Hussein in 1998); and hence even after 9/11, the US and the UK had a hard time convincing other countries that invading Iraq was warranted. Then the Bush and Blair administrations made the argument that, instead, it was Hussein who bore the burden of proof - to show that Iraq had no WMD, by cooperating with inspectors, disclosing any WMD or precursor material and disarming. Shifting the burden of proof was a centerpiece of Secretary of State Colin Powell's landmark speech to the UN on February 5, 2003, presenting the case for war. Canadian Foreign Minister Bill Graham commented that the speech "amounts to a transfer of the burden of proof from the United States to Saddam Hussein.” ${ }^{21}$ Secretary Powell reiterated the burden-shifting point to the UN Security Council a month later. ${ }^{22}$ Back in December 2002, White House Press Secretary Ari Fleischer had said: “The burden of proof lies with Saddam Hussein."23 Madeleine Albright, secretary of state in the Clinton Administration, had agreed: "there's no question that the burden of proof is on Iraq. I mean we've all said that; everybody believes that.”24

This is precisely the same type of shift in the burden of proof advocated under the Precautionary Principle: instead of the government regulatory agency having to prove that a substance or activity is dangerous,

"the applicant or proponent of an activity or process or chemical needs to demonstrate that the environment and public health will be safe. The proof must shift to the party or entity that will benefit from the activity and that is most likely to have the information., 25

Like Secretary Powell, Prime Minister Blair made the same move: 
"Blair's position can just as well be expressed in the more neutral language of precaution. What lawyers, bureaucrats and even some philosophers like to call the Precautionary Principle states that when faced with risks with uncertain and potentially catastrophic downsides, it's always better to err on the side of caution. In such circumstances, the burden of proof is said to lie with those who downplay the risk of disaster, rather than with those who argue that the risks are real, even if they might be quite small. This appears to be Blair's current position on the war in Iraq.”26

To be sure, it can be difficult for the actor facing government action to prove that its products are safe or that it has no WMD, because it is difficult to prove a negative. If Hussein had disclosed some WMD material, that would have incited greater suspicion of finding further hidden WMD at risk of imminent use, not relief that he had come clean. If Hussein had insisted he had no WMD, that would have been called stonewalling; the inability of UN and International Atomic Energy Agency (IAEA) inspectors to find WMD after they returned to Iraq in 2002 was treated as unpersuasive by US intelligence agencies. ${ }^{27}$ The tactic of shifting the burden of proof, while potentially a sensible incentive to elicit important information, does make the case for government action harder to resist - which is precisely the objective of the burden-shifting tactic in both the Precautionary Principle and the Bush counterterrorism strategy.

\section{$\underline{\text { Parallel critiques of precaution }}$}

Further indication of the shift to precaution comes from the criticisms leveled against the new strategy. The criticisms of precaution against terrorism are virtually identical to the criticisms of precaution on environmental risks - but on the opposite political feet. When the US announced its new doctrine of anticipatory war in September 2002, German Foreign Minister (and Green Party vice-chairman) Joschka Fischer worried aloud to the UN General Assembly:

"To what consequences would military intervention lead? ... Are there new and definite findings and facts? Does the threat assessment justify taking a very high risk? ...we are full of deep skepticism regarding military action..."28

While the US government wanted fast and forceful action to prevent the next terrorist attack, despite the uncertainty of the threat, its detractors in Europe wanted more evidence - "findings of fact" and a "threat assessment," in Fischer's words - and deliberation before acting (ironically, precisely the stance that European Greens oppose as an obstacle to precautionary regulations on food safety and the environment). After the war in Iraq and the failure to find compelling evidence that Iraq was creating or deploying WMD, ${ }^{29}$ critics, such as columnist Paul Krugman, have questioned whether the US and the UK acted prematurely, ${ }^{30}$ in effect, whether the US and the UK "cried wolf” and undertook precaution based on a false positive. This same critique was leveled by skeptics of precaution in the environmental arena. ${ }^{31}$ In September 2003, chief UN weapons inspector Hans Blix told a Greek newspaper that:

"It is clear that the critical thinking we applied led us less astray than did the assertive thinking of the US administration ... We never said there were weapons of mass 
destruction. What we said was that the Iraqis could not answer all our questions regarding their arsenal. But, for the Bush administration, 'unaccounted for' equaled 'existing.,’32

The Bush position described by Blix is the same as that of advocates of precautionary environmental regulation, who say that "absence of evidence" of harmfulness "is not evidence of absence" of harmfulness, and therefore that regulation should go forward to address the potential risk even without clear evidence. Even the then-Republican chair of the House Intelligence Committee, J. Porter Goss (now the president's appointee heading the CIA), and the Democrat ranking member of the Committee, Jane Harman, sent a joint letter to the Bush administration complaining that the case for invading to seize WMD in Iraq had been based on intelligence beset with "too many uncertainties"33 - precisely the critique that the Precautionary Principle aims to overcome. The New York Times editorialized: "If intelligence and risk assessment are sketchy - and when are they not? - using them as the basis for pre-emptive war poses enormous dangers." ${ }^{34}$ Replace "pre-emptive war" with "precautionary regulation," and one has the standard industry line against health and environmental policy.

Meanwhile, the Bush administration itself has been a critic of precaution on food and environmental risks, emphasizing uncertainty as a reason not to act. "Mr. Bush, explaining to senators why he opposed the Kyoto protocol on global warming, spoke of the 'incomplete state of scientific knowledge of the causes of, and solutions to, global climate change,'” according to Anthony Lewis writing in the New York Times. ${ }^{35}$ The Bush administration official in charge of regulatory policy has called the Precautionary Principle "a mythical concept, perhaps like a unicorn.”36

The war in Afghanistan was precautionary in the sense of anticipating and attempting to prevent Al Qaeda's next attack, but it was also in direct response to clear evidence of threat, namely the attacks of 9/11. The war in Iraq was far more precautionary. The evidence of risk was highly uncertain before the war, with speculative and circumstantial evidence of WMD and tenuous links asserted between Al Qaeda and Iraq. But the small and uncertain probability of a catastrophic outcome was cognizable, and is precisely the situation to which the Precautionary Principle speaks. ${ }^{37}$ Now, with several extensive reports in both the US and the UK finding that no WMD threat existed in Iraq before the war, and the US search for WMD in Iraq having officially ended on January 11, 2005, the invasion of Iraq appears to have been premised on a serious false positive. ${ }^{38}$ This simply underscores the degree to which the war itself was a highly precautionary move: undertaken in anticipation of a serious threat but under enormous uncertainty about the risk, with very little good evidence to back it up, and with far greater concern about false negatives (WMD unknown but existing) than about false positives (WMD claimed but not existing).

To be sure, it is possible that the WMD did exist but have been moved or hidden someplace else. And, even if the WMD did not exist, the ex ante risk assessment may have been sufficiently worrisome to warrant precaution despite the high chance of error. ${ }^{39}$ These possibilities are part and parcel of precaution against an uncertain risk with a high damage worst-case scenario. Alternatively, perhaps the risk of WMD was not the real underlying motivation for the war; perhaps the real reason was liberating the Iraqi people, spreading democracy, deterring other rogue states, or even seizing control of oil resources, or something else. But critics of precaution 
in the health and environmental arena make the same complaint: that precaution is a cover for other motives, such as disguised trade protectionism. The basic point remains that the new National Security Strategy, and the stated rationale for specific actions taken pursuant to it (including the war in Iraq), are the Precautionary Principle applied to terrorism. ${ }^{40}$

\section{Precaution, pre-emption and prevention}

The degree to which the new Bush doctrine is highly precautionary is evident from the corresponding terminologies of regulation and war. In the regulatory arena, the Precautionary Principle advocates intervention to forestall uncertain risks. Some authors distinguish "precautionary" regulation from "preventive” regulation, arguing that precaution applies to unknown risks whereas prevention applies to known risks. ${ }^{41}$ This distinction is vague at best, because there is no such thing as a "known" risk; all risks are uncertain, and there are simply degrees of uncertainty (hence degrees of precaution). But in any case, the distinction between "precautionary" and "preventive" regulation corresponds fairly closely to the parallel distinction between "preventive" and "preemptive" war, respectively. Preemptive war (like preventive regulation) is anticipatory self-defense against an imminent (i.e., "known”) threat. Preventive war (like precautionary regulation) is more aggressive: it is anticipatory self-defense without an imminent threat. Preventive war is more aggressive, more anticipatory, more likely to target false positives and less accepted (if at all) under international law, than preemptive war. ${ }^{42}$

Traditionally, under international law, preemptive war is legal if in self-defense against imminent attack, but not against highly uncertain threats. Emmerich de Vattel wrote that "A Nation has the right to resist the injury another seeks to inflict upon it, and to use force ... against the aggressor. It may even anticipate the other's design, being careful, however, not to act upon vague and doubtful suspicions, lest it should run the risk of becoming itself the aggressor." 43 US Secretary of State Daniel Webster articulated the criteria for legitimate preemptive war in the Caroline incident: an intrusion into the territory of another state can be justified as an act of self-defense only in those "cases in which the necessity of that self-defense is instant, overwhelming and leaving no choice of means and no moment for deliberation." ${ }^{44}$ Moreover, the force used in such circumstances has to do "nothing unreasonable or excessive; since the act, justified by the necessity of self-defense, must be limited by that necessity, and kept clearly within it."45 Similarly, Michael Walzer argues that "Both individuals and states can rightfully defend themselves against violence that is imminent but not actual; they can fire the first shots if they know themselves about to be attacked," but that preventive war is not just because there is not yet a real prospect of being attacked. ${ }^{46}$ Historically, the US has engaged in preemptive military strikes against imminent threats on numerous occasions. ${ }^{47}$

The UN Charter requires that members settle their disputes through peaceful means - members should refrain from the threat or use of force (Art. 2(3)-(4) of UN Charter). The only stated exceptions to this rule are found in Art. 51 - which preserves the right of any member to engage in self-defense against armed attack - and Art. 42 - which allows for collective actions through the Security Council. No explicit exception is made for preventive war. Article 51 provides that "Nothing in the present Charter shall impair the inherent right of individual or collective self- 
defense if an armed attack occurs against a Member of the United Nations, until the Security Council has taken measures necessary to maintain international peace and security.”

Some argue that this language limits self-defense to retaliation only after "an armed attack occurs," but others contend that such an interpretation is too narrow because it would bar preemptive self-defense even against a clearly imminent attack. ${ }^{48}$ The advent of WMD held by rogue states or terrorists is forcing legal experts to revisit the distinction between preemptive and preventive war. David Ackerman notes, "[T]here is at present no consensus either in theory or practice about whether the possession or development of weapons of mass destruction (WMD) by a rogue state justifies the preemptive use of force. Most analysts recognize that if overwhelmingly lethal weaponry is possessed by a nation willing to use that weaponry directly or through surrogates (such as terrorists), some kind of anticipatory self-defense may be a matter of national survival; and many - including the Bush administration - contend that international law ought to allow, if it does not already do so, for the preemptive use of force in that situation. But many states and analysts are decidedly reluctant to legitimate the preemptive use of force against threats that are only potential and not actual on the grounds the justification can easily be abused." ${ }^{49}$ Regarding the war in Iraq, Ackerman observes that "Iraq had not attacked the U.S., nor did it appear to pose an imminent threat of attack in traditional military terms. As a consequence, it seems doubtful that the use of force against Iraq could be deemed to meet the traditional legal tests justifying preemptive attack. But Iraq may have possessed WMD, and it may have had ties to terrorist groups that seek to use such weapons against the US." 50

Anne Marie Slaughter and Lee Feinstein argue that the rules governing the use of force, developed in 1945 and contained in the UN Charter, were designed for an era in which threats emerged from sovereign states and conventional armies. "In the twenty-first century," they argue, "maintaining global peace and security requires states to be proactive rather than reactive." 51 The gravest threat, they argue, is posed by states pursuing WMD that are headed by rulers with no internal checks on their power or who support terrorists. Under these circumstances, there should be a "responsibility to prevent" acquisition of WMD. "In a world in which ... governments can get access to the most devastating weapons and make them available to terrorists, we must take action," they assert. The rules regarding use of force "can continue to serve us well only if they are reviewed and updated to meet a new set of threats. Accepting a collective duty to prevent is the first step toward sustained self-protection in a new and dangerous era." 52

Law professor John Yoo, who served in the Bush Justice Department, also argues that national self-defense must be understood to allow preventive attacks against uncertain threats of WMD. ${ }^{53}$ He goes further to propose that the right of national self-defense in Article 51 be reconceived as a cost-benefit test, weighing the probability and consequence of a WMD attack, the effectiveness of the preventive measure in avoiding such attack, and the costs of the attack. That approach would authorize preventive measures long before "an armed attack occurs," but it would constrain preventive war by the cost-benefit test. (Whether precautionary regulation in the health and environmental arena can be consistent with cost-benefit analysis remains in controversy. Many advocates of the Precautionary Principle see it as authorizing much government action that would not pass an economist's cost-benefit test, a test that they view as flawed and unduly 
constraining. ${ }^{54}$ Others have argued that precaution can and should be reframed in terms of a costbenefit test with appropriate premia for catastrophic risks. ${ }^{55}$ )

Even if preventive war (precaution) is warranted against uncertain risks of WMD, there remains the question of who should authorize such action. Slaughter and Feinstein referred to a "collective” responsibility to prevent. The High Level Panel on Threats, Challenges and Change commissioned by the UN Secretary General and transmitted to the UN on December 1, 2004, addressed anticipatory self-defense in precisely this situation: scenarios involving terrorists, weapons of mass destruction and irresponsible states. The panel (whose membership included Brent Scowcroft, former national security adviser to President George H. W. Bush) agreed that preventive measures may be needed and justified "where the threat in question is not imminent but still claimed to be real: for example the acquisition, with allegedly hostile intent, of nuclear weapons-making capability ... [but] Can a State, without going to the Security Council, claim in these circumstances the right to act, in anticipatory self-defense (sic), not just preemptively (against an imminent or proximate one) but preventively (against a non-imminent or nonproximate one)?" ${ }^{56}$ Recognizing the argument in favor of precaution, "that the potential harm from some threats (e.g., terrorists armed with a nuclear weapon) is so great that one simply cannot risk waiting until they become imminent, and that less harm may be done (e.g., avoiding a nuclear exchange or radioactive fallout from a reactor destruction) by acting earlier," the answer for an individual state, the High Level Panel advised the Secretary General, should still be no.

"The short answer is that if there are good arguments for preventive military action, with good evidence to support them, they should be put to the Security Council, which can authorize such action if it chooses to. If it does not so choose, there will be, by definition, time to pursue other strategies, including persuasion, negotiation, deterrence and containment - and to visit again the military option. ... For those impatient with such a response, the answer must be that, in a world full of perceived potential threats, the risk to the global order and the norm of non-intervention on which it continues to be based is simply too great for the legality of unilateral preventive action, as distinct from collectively endorsed action, to be accepted. Allowing one to so act is to allow all. ...the international community does have to be concerned about nightmare scenarios combining terrorists, weapons of mass destruction and irresponsible States, and much more besides, which may conceivably justify the use of force, not just reactive but preventively and before a latent threat becomes imminent. The question is not whether such action can be taken: it can, by the Security Council as the international community’s collective security voice, at any time it deems that there is a threat..." ${ }^{57}$

In a companion op-ed article, UN Secretary General Kofi Annan summarized the panel's criteria for preventive war:

"The use of force: ...

- Seriousness of threat: Is the threat serious enough to justify prima facie the use of force?

- Proper purpose: Is the primary purpose of the proposed use of force to halt or avert the threat in question?

- Last resort: Has every non-military option been explored and exhausted? 
- Proportional means: Is the force proposed the minimum necessary to meet the threat?

- Balance of consequences: Is it clear that the consequences of action will not be worse than the consequences of inaction?

The report sees no need to amend Article 51 of the UN Charter, which preserves the right of all states to act in self-defense against armed attack, including the right to take preemptive action against an imminent threat. However, in the new security environment in which we live, states may also fear threats that are neither imminent nor proximate, but which could culminate in horrific violence if left to fester. The Security Council is already fully empowered by the charter to deal with these threats. It must be prepared to do so, taking decisive action earlier than in the past, when asked to act by states that have based their claims on reliable evidence."58

The point here is not to settle the legal question whether preemptive or preventive war by individual states violates international law, nor whether that is what international law should hold, nor whether the current war in Iraq would satisfy the criteria for preemptive self-defense, nor whether the international law of war really influences governments' behavior. The point here is merely to say that the Bush doctrine announced in 2002, calling for unilateral anticipatory military attacks against potential threats before evidence of an imminent threat has been shown, amounts to a highly precautionary strategy to combat the risks of terrorism and WMD, with uncertainty being no excuse for inaction. It is substantially more anticipatory against substantially more uncertain risks than is preemptive self-defense, and than is collective prevention by the UN Security Council. ${ }^{59}$ Whether the Bush doctrine of precautionary counterterrorism is desirable or not depends on its consequences, which are evaluated below.

One can of course envision other precautionary counterterrorism strategies that the Bush administration has not taken. For example, the government could forcibly confine all members of the potential terrorists' ethnic group in an internment camp, with no evidence that any of these people poses a real threat, but acting on the uncertain risk that they might cause serious harm. The US adopted such a policy with respect to Japanese-Americans in World War Two, and some staunch counterterrorism advocates propose a similar policy today. ${ }^{60}$ Another highly precautionary measure would be to ban all entry to US borders by travelers from certain countries. Another would be to wage preventive war against additional countries, such as Iran, Pakistan and North Korea. The Bush administration has not taken these steps, perhaps because it is distracted and bogged down in Iraq, or perhaps because it recognizes the adverse consequences of excessive precaution - the topic of the following section.

\section{Why the precautionary approach now?}

The US and other countries have used preemptive strikes in the past, but the adoption of an overall strategy of pre-emption and preventive war is a new frontier. ${ }^{61}$ Several factors drove this shift to a more precautionary approach in US and UK strategy. 


\section{$\underline{\text { Strategic need }}$}

First, as noted above, experts sought the shift on the grounds that the Cold War strategies of deterrence and containment would be far less effective against non-state actors using suicide surprise attacks, and that such attacks could be catastrophic. This therefore created the need for a more anticipatory strategy that incapacitates the threat before it occurs. But the application of this strategy to specific places (such as Afghanistan and Iraq) depends on risk assessments intelligence estimates and threat information - that appear to have overstated the risk of WMD in Iraq (a false positive). The Economist magazine initially urged "The case for war" in the August 3, 2002 issue, and later ventured "The case for war - revisited" in the July 19, 2003 issue after WMD failed to turn up, but then ran two cover photos of President Bush and Prime Minister Blair with the disillusioned headlines "Wielders of mass deception?” on October 4, 2003, and then "Sincere deceivers" on July 17, 2004.

\section{$\underline{\text { Risk assessment and its errors }}$}

Second, then, was the overstatement of risk by expert risk assessors (the intelligence community) and by policy officials. For example, before the war, CIA Director George Tenet told President Bush that the case for finding WMD in Iraq was a "slam dunk," (in 2005 he said those were, "the two dumbest words I ever said”). ${ }^{62}$ Relying on that assessment, President Bush said in his 2003 State of the Union speech that Iraq was seeking materials for nuclear weapons from Niger, a claim that later appeared to have been false and based in part on a forged document. Secretary of State Powell enumerated ostensible evidence of WMD in Iraq to the UN in February, 2003. The UK government said that Iraqi forces could deploy WMD within 45 minutes. Yet after the war, no WMD were found, and high-level panels called the prewar assessments “dead wrong."63 These overstatements were in part a reaction to the 9/11 surprise attacks, and the intelligence failures they had represented - that is, an effort to avoid making the same false negative error a second time, especially if the second time could be with WMD.

The overstatement of risk by expert risk assessors bears detailed scrutiny. The claim of WMD in Iraq - the central premise of the precautionary strategy to wage preventive war - was crucial in motivating both leaders and the public to go to war, but appears in retrospect to have been a false positive. Past false negatives (neglect) can spur future false positives (overreaction). Analysts have been wrong about WMD programs many times in the past. Cases include the Soviet Union in 1949, China in 1964, India in 1974, Iraq in 1991, North Korea in 1994, Iraq in 1995, India in 1998, Pakistan in 1998, North Korea in 2002, Iran in 2003 and Libya in 2003. "In each of these cases,” Peter Feaver explains, “the WMD program turned out to be more advanced than the intelligence community thought." ${ }^{24}$ This list of false negative failures helps to explain why the intelligence community might have overstated its findings - determined to get it right this time especially in the immediate aftermath of the surprise attacks of 9/11. Paul Pillar argues that the major failure was not of the intelligence agencies neglecting the risk, but of the policy officials neglecting the intelligence. He notes that attacks in the 1990s made intelligence agencies well aware of Al Qaeda, that the CIA created its first-ever unit aimed at a single individual (Osama bin Laden), and that the Clinton administration considered striking bin Laden several times but held back for fear of missing, collateral damage or other concerns. ${ }^{65}$ There was significant 
warning of Al Qaeda's intent to strike in the US - such as the famous Presidential Daily Briefing of August 6, 2001 ("Bin Laden Determined to Strike Within the US"), as well as the earlier National Intelligence Estimate (NIE) produced in 1995, warning that Islamist terrorists might try to blend into US immigrant Muslim populations and use conventional weapons or civil aviation to attack landmarks such as Wall Street and the White House. ${ }^{66}$ There were also clues of the hijackers' plans at regional FBI offices that did not get adequate attention, as cited by the 9/11 Commission Report. ${ }^{67}$ It is easy in hindsight, knowing which attack actually occurred, to forget that before 9/11 these strands competed for attention amid many other hints and threats, and it was not simple to sort the true positives from the false ones. Still, the false negative of 9/11 was stunning. "Though analysts have been wrong on major issues in the past, no previous intelligence failure has been so costly as the September $11^{\text {th }}$ attacks," the Senate Select Committee on Intelligence concluded in 2004. While they found no evidence that analysts had been politically pressured to exaggerate the links between Al Qaeda and Hussein, or the progress of Iraq's WMD programs, it is easy to imagine that analysts might have felt pressured by their own earlier mistakes, especially the most recent one that perhaps could have prevented the deaths of nearly 3,000 innocent civilians. ${ }^{68}$ The Butler Report on UK intelligence observed: "It is a well-known phenomenon within intelligence communities that memory of past failures can cause overestimation next time around." 69

The Senate Select Committee on Intelligence concluded that most of the key judgments of the National Intelligence Estimate of October 2002, Iraq's Continuing Programs for Weapons of Mass Destruction, were either "overstated or were not supported by the underlying intelligence reporting."70 The intelligence community did not adequately explain its uncertainties to policy makers, especially in regard to Iraq's nuclear program. It suffered a "group think" mentality that led collectors and managers to interpret ambiguous evidence as conclusive. Normal procedures for probing assumptions, such as "red teams," were not utilized. When dual-use equipment was discovered in Iraq, the community ignored information that should have made it clear that some of the equipment was actually being used for conventional purposes. "None of the guidance given to human intelligence collectors suggested that collection be focused on determining whether Iraq had WMD. Instead, the requirements assumed that Iraq had WMD, and focused on uncovering those activities..."71 There was no probing of presumptions. The reason there were no spies on the ground in Iraq, intelligence officials told the committee, was that it was too difficult and dangerous to sustain an intelligence operation there. ${ }^{72}$

Improving the odds of distinguishing true positives, false positives and false negatives requires real-time intelligence of a type not currently available, at least according to a number of recent assessments of the US intelligence community. A commission appointed by President Bush concluded in March 2005 that the US "knows disturbingly little about the nuclear programs of many of the world's most dangerous actors," that knowledge about the spread of biological weapons programs is also inadequate and, bluntly, that US agencies were "dead wrong” about WMD in Iraq. ${ }^{73}$ Assessments by the CIA of Iraq's capabilities prior to the war in Iraq were “crippled by its inability to collect meaningful intelligence” on Iraq’s WMD programs. Instead, intelligence analysts relied on "old assumptions" and then "swathed them in the mystique of intelligence, providing secret information that seemed to support them but was in fact nearly worthless, if not misleading." 74 The commission also accused the intelligence community of having "an almost perfect record of resisting external recommendations," and of refusing to 
adapt to a world of very different threats from those faced during the Cold War." 75 The Senate Intelligence Committee report on the quality of pre-war intelligence on Iraq found that the US had no sources in Iraq collecting intelligence on Iraq's WMD programs after 1998 and concluded that the intelligence community relied so heavily on foreign government services and third party reporting that it was putting the nation at risk of manipulation by other governments. ${ }^{76}$

While these review commissions emphasized that the intelligence on Iraq overstated the risk of WMD, the president emphasized the opposite problem: "Our collection and analysis of intelligence will never be perfect, but in an age where our margin for error is getting smaller, in an age in which we are at war, the consequences of underestimating a threat could be tens of thousands of innocent lives," Bush said, promising intelligence reforms that would "allow us to identify threats before they fully emerge so we can take effective action to protect the American people.”77 This approach to uncertainty, as we have seen, is the Precautionary Principle in action.

Senator Jay Rockefeller (D-West Virginia), the vice-chairman of the Senate Select Intelligence Committee, called the intelligence "profoundly flawed on all subjects," and also accused the Bush administration of "exaggerating intelligence" and "going beyond it to try to convince the American people that war was the way to go.”78 The subsequent assessment by the panel commissioned by President Bush (co-chaired by Judge Laurence Silberman and Senator Charles Robb (D-Virginia)) concluded that the NIE of October 2002 was, as noted above, "dead wrong," and called the president's Daily Briefs even "more alarmist and less nuanced" than the NIE. ${ }^{79}$ Senate Select Intelligence Committee Chair Pat Roberts agreed with the new panel report. ${ }^{80}$

Similarly, the report by the committee chaired by Lord Butler, which assessed the quality of UK intelligence prior to the war, found that evidence was stretched to the "outer limits" in making the case for war ${ }^{81}$ and that "group-think" was a major problem. ${ }^{82}$ Neutrality and objectivity were compromised by the government's need for a document it could draw on to advocate the case for war, putting the intelligence services under great strain. ${ }^{83}$ The UK government dossier of 24 September 2002 that made the case for war in Iraq omitted many caveats about the "unclear" and "uncertain" nature of the intelligence, suggesting that it was "fuller and firmer" than it actually was). ${ }^{84}$ In the dossier, "points were run together and the caveats on the intelligence were dropped" and "warnings" on the "limited intelligence base” were omitted. ${ }^{85}$ For example, the famous claim that Iraq could launch an attack with WMD within " 45 minutes” was meant to refer to battlefield deployment in Iraq, not a strike in Europe, but that qualification was dropped as drafts of the dossier were edited, and the claim itself is now deemed doubtful). ${ }^{86}$ The Butler Report did note some intelligence successes, such as the discovery of a Pakistani scientist's sales of nuclear know-how to other countries.

The post-9/11 overstatements of Iraqi WMD were not the first time that intelligence agencies fell into the trap of overestimating the threat this time because last time it was underestimated. In his assessment of Israeli intelligence failures in regard to Iraq, retired Israeli General Shlomo Brom attributed the adoption of worst-case scenarios to a desire to avoid blame for underestimating threats. The intelligence failure prior to the Yom Kippur War created a culture of "assigning culpability and punishing those responsible." Analysts thus have an incentive to exaggerate the enemies' capabilities because they "feel that by giving bleak assessments they decrease the threat 
to themselves.” If the assessment is correct, they will be treated as heroes, he wrote, and if it is wrong, no one will pay much attention "because everyone will be pleased that their bleak prophecies did not materialize." ${ }^{87}$ And it is worth recalling that Iraq had claimed it possessed WMD in the 1990s, including several tons of the nerve agent VX, as well as botulinum toxin and aflatoxin - the latter a slow-acting carcinogen with no battlefield utility, implying its sole use to terrorize civilian populations. ${ }^{88}$ An internal CIA analysis argued that although mistakes were evident in retrospect, the prewar assessment of Iraq's WMD was reasonable based on the information that was available at the time. ${ }^{89}$

\section{Psychology: availability, fear and dread}

In addition to the strategic need for a proactive response to non-state actors using suicide, and the overstatement of risk by expert risk assessors and policy officials, a third key driver of the shift to precaution was the psychological element: availability, fear and dread. The availability heuristic is the tendency to respond aggressively to alarming events that are "available" or vivid in people's minds. ${ }^{90}$ People tend to exaggerate the likelihood of such events (relative to risks that are statistically more likely) because they are easy to imagine or recall, and to support more stringent protective measures against available risks. Yet low-probability, high-consequence catastrophic events, such as a major terrorist attack or an asteroid collision, are by definition rare, and so not easily available. In general, therefore, people tend to understate the risk of lowprobability, high-consequence events such as terrorist attacks, ignoring or lampooning remote chances of catastrophes (even when such events warrant precaution on an expected value basis), perhaps because they lack experience with such rare extreme events or because the mind avoids the mental burden of contemplating the horrific. ${ }^{91}$ This leads to false negative errors, catastrophic surprise and hindsight recriminations. But once such an event, or one similar to it, has recently occurred, the availability heuristic is triggered and people tend to overstate the risk of another catastrophic event. " ${ }^{92}$ "US citizens and their elected leaders respond far more readily to dramatic events in their midst than to warnings and analyses about threatening events yet to occur."93 "Experience has shown that major policy changes tend to come only from actual disasters." 94 One available event can set in motion a cascade of public clamor for stringent protective measures against similar events even if they are not causally connected, such as fear of genetically modified foods driven by mad cow disease, and even if other risks deserve more prospective attention. ${ }^{95}$ The adoption of major health and environmental legislation was similarly driven by crisis events such as the burning of the Cuyahoga River, pollution in Lake Erie and the discovery of toxic waste in Love Canal. ${ }^{96}$

Consistent with the availability heuristic, President Bush and Vice President Dick Cheney have expressly justified the war in Iraq as a response to 9/11, even if there was no evidence linking the two. Although experts had been warning for years of the potential for mass-casualty terrorism and of Al Qaeda's likely involvement in such attacks, with the highly visible 9/11 event terrorism suddenly rose to the top of the national agenda. Earlier, the US had not made aviation risks a priority because there had been no hijackings of US airplanes since 1986 - no available events to spark concern. ${ }^{97}$ Other terrorist attacks against the US were seen as far away (e.g. Lebanon, Kobar Towers, USS Cole) or as one-time crimes (Oklahoma City). Still, the government did take steps after these events to harden government facilities against attack and to 
strike at Al Qaeda in Afghanistan and Sudan. Yet it is unclear why the US did not react more strongly to the 1993 World Trade Center bombing - perhaps because it was not highly damaging. After the 9/11 attacks, and the anthrax letters and sniper attacks in Washington DC, the US public was far more ready to support aggressive counterterrorism policies because of such psychological availability, even if the probability of such attacks remained roughly the same as it had been since at least 1993. Many proverbial barn doors were closed after 9/11, even if those barn doors had little to do with the likelihood of future horses escaping (and yet other doors, such as ports and mass transit, remained relatively open).

Meanwhile, across the Atlantic, “[i]t is only in those West European states which have suffered protracted and destructive campaigns of terror that the existence of special antiterrorist legislation has been accepted,” writes Chalk. ${ }^{98}$ After 9/11, Prime Minister Blair admitted that he was deeply influenced by its horrors in his assessment of the threat of Iraq. While he had already been deeply concerned about the proliferation of WMD and the threat posed by bin Laden, "after September $11^{\text {th }}$ it took on a completely different aspect ... what changed for me with September $11^{\text {th }}$ was that I thought then you have to change your mindset ... you have to deal with this because otherwise the threat will grow," as quoted in the Butler Report. ${ }^{99}$

In a sense, this psychological and political dynamic renders the actions taken less strictly precautionary: they are reactions to the recent past crisis as much as or more than anticipatory protections against uncertain future risks. But even though driven by past crises, the content of the policies adopted is strongly precautionary, authorizing government to act aggressively to prevent uncertain future risks.

Here the availability heuristic was compounded by dread - the abject fear of sinister, mysterious or unnatural risks. ${ }^{100}$ The envisioned threat - of WMD being wielded by suicidal foreign religious fanatics who hate the US - is an inescapable source of dread. Dread can motivate decision-makers to take particularly aggressive actions to avoid risk and can lead the public to support leaders who are seen to take aggressive action. When dangers evoke a strong sense of dread, policy makers are particularly susceptible to implement risk-reduction policies with little regard to countervailing dangers. ${ }^{101}$ It has long been observed that the things that frighten us most are often quite different from those most likely to harm us. ${ }^{102}$ Psychologists have found that fear is disproportionately evoked by certain qualitative attributes of risks, including: involuntary exposure, unfamiliarity, invisibility, catastrophic potential, latency and uncertainty. ${ }^{103}$

Terrorism - especially with WMD - is unusual in that it possesses all of the characteristics that psychologists have shown to be conducive to disproportionate dread. The radius of fear generated by a terrorist attack far exceeds the zone of injury and death. It is a form of psychological warfare whose goal is to bolster the morale of its supporters, and demoralize and frighten its target audience - victims and their sympathizers. US citizens are now living in a dread-full age - of shoe-bombers and orange alerts, of suicide-murderers and dirty bombs, of pronouncements by our enemies that they will destroy our country.

Compounding and amplifying this dread is the element of "evil.” Evil is difficult to define, let alone to measure. In the 9/11 terrorist attacks, many of the classic components of evil - including malice, premeditation, surprise attack without warning or ultimatum, the killing of thousands of 
innocent civilians and suicide attack - have "rarely been so well combined," according to Susan Nieman. ${ }^{104}$ Evil, disgust and fear seem to be related. What is evil disgusts and frightens us; what disgusts us may seem tainted with evil. ${ }^{105}$ Evil evokes maximal dread. If a leader can persuade us we are fighting evil itself, we are more likely to make sacrifices, and more prone to throw caution aside in regard to new risks introduced by our actions. Hence, a war against evil is proclaimed by both sides - by the terrorists rallying jihad, and the target countries rallying the war on terror. Dread of evil cements societies, Jeremy Bentham observed, more than the hope for good. ${ }^{106}$ Thus, four days after the 9/11 terrorist strikes, President Bush announced that his administration would "rid the world of evil-doers." ${ }^{107}$ He has referred to rogue states seeking WMD as an "axis of evil."

The mission of fighting evil, articulated during the period of maximal pain and confusion in the immediate aftermath of the 9/11 attacks, made highly precautionary policy remedies that would have been unthinkable only days before the attacks suddenly seem urgent. The administration announced that it would hold suspects in detention indefinitely, without charges and with no access to lawyers. Congress approved new legislation, the USA Patriot Act, in the space of weeks, and reorganized much of the government into the Department of Homeland Security and a new intelligence structure. The US, UK and allies invaded Afghanistan soon after, and later Iraq.

\section{Analyzing the consequences of precaution against terrorism and WMD}

We start from the basic premise that governments should think things through before taking action. The world is complex and interconnected, and interventions will have multiple consequences, both intended and unintended. ${ }^{108}$ Successful counterterrorism strategy and action requires consideration of its expected consequences before adopting policies or deploying forces. The need for such impact analysis is heightened by the strategic shift from deterrence and containment to precaution and preventive war. ${ }^{109}$

In the health and environmental arena, impact analysis of regulatory measures is routine. It is required in the US by Presidential Executive Order and in the EU by the Better Regulation initiative. A similar analytic approach should be adopted for precaution in the national security arena. The 9/11 Commission urged that the US needs "a forward-looking strategic plan systematically analyzing assets, risks, costs, and benefits” of counterterrorism options. ${ }^{110}$ Similarly, Secretary of Defense Donald Rumsfeld asked the 9/11 Commission in October 2003, "Are we capturing, killing or deterring and dissuading more terrorists every day than the madrassas and the radical clerics are recruiting, training and deploying against us? Does the US need to fashion a broad, integrated plan to stop the next generation of terrorists? The US is putting relatively little effort into a long-range plan, but we are putting a great deal of effort into trying to stop terrorists. The cost-benefit ratio is against us! Our cost is billions against the terrorists' cost of millions."111 Lieutenant Colonel Michael Weeks proposes that the new National Security Strategy be accompanied by the use of concepts from economic analysis to help make decisions. "We must make new assessments of our capabilities and consider both direct and indirect costs [including] ... [c]ollateral damage... With precision weapons ... we have the ability to put a bomb through a particular window. What we don't always have is the 
technology to decide which window we should choose. ... If we are to make efficient decisions about where to intervene, we must be able to assess the costs and benefits of such actions.... The primary point is that we should make a full accounting of the elements in the equation in order to arrive at the appropriate decision." ${ }^{112}$

The purpose of evaluating the consequences is not to arrive at a precise monetary calculus of a proposed action's net gains or losses. Rather, it is to ensure that decision-makers consider and do not neglect all the important consequences of a proposed action (compared to alternative actions). It is a cognitive exercise rather than an accounting task. ${ }^{113}$ It should include qualitative as well as quantified impacts.

A full portfolio analysis of precaution against a risk compares the reduction in target risk (TR) plus ancillary benefits (AB), versus the costs (C) plus increases in countervailing risks (CR). ${ }^{114}$ Analyses should be undertaken both ex ante and ex post. Ex ante analysis is needed to inform and shape decision-making before committing resources, adopting policies and using force. It helps identify the potential consequences, both intended and unintended, of various alternative actions across various alternative scenarios. Ex post analysis is needed to adjust actions in light of new information, and to validate and improve ex ante analysis methods.

Such analysis can be a powerful guide to intelligent decision-making in counterterrorism. At the same time, the case of counterterrorism can provide a lesson for risk analysts: the need to foresee subsequent moves taken by terrorists in response to initial counterterrorism measures. More generally, risk analysis has too often assumed a simple direct relationship between regulatory measures and the change in emissions or risk, neglecting responsive behavior by the regulated actors. Risk analysis could benefit from approaches (such as general equilibrium analysis and multi-period games) that take account of responsive actors - actors who take evasive or reallocative steps in response to risk management interventions. Terrorists clearly respond strategically to defensive measures, but this general approach will also be useful for analyzing the effects of measures directed at adaptive pathogens and law-abiding business firms.

In this section we present a framework for a full portfolio analysis of precaution against terrorism. We focus on the war in Iraq as the leading example of this strategy. Caveat: Our analysis is necessarily limited to publicly available information, so we cannot assess impacts as fully as the government defense and intelligence agencies could if they chose to do so, but we can suggest a framework for analysis of the types and directions of impacts that they might neglect if they were not put to the challenge of such analysis. Second caveat: Although we unavoidably take account of information gleaned since the invasion (ex post), such as the apparent absence of WMD, we also attempt to consider how an ex ante analysis would have looked before the decision to engage in preventive war. Ex ante, on expected value criteria, it is possible that even a low probability of WMD existing in Iraq, combined with high damages from their use, weighed against predictions of low cost and low countervailing risk, could have justified precautionary action. We doubt that a careful analysis of these impacts was made ex ante, and we suggest that had it been, the calculus could well have shown that the decision should have been different because the likely costs and countervailing risks were quite significant. Third caveat: We recognize that many readers will approach this question with their minds already made up, either for or against the war, and will accept or reject particular aspects 
of our analysis so as to render the whole consonant with their pre-existing conclusion.

Nonetheless, our aim here is to persuade the reader that a full analysis of consequences would improve decision-making about counterterrorism, especially precautionary actions. As we have suggested, precaution against terrorism poses a reversal of typical political positions, and analysis of the full portfolio impacts should appeal to thoughtful minds on all sides.

\section{$\underline{\text { Reduction in target risk }}$}

Risk is a combination of probability and severity. Low probability is not by itself a sufficient reason to neglect a risk with potentially severe consequences; ${ }^{115}$ what matters is the expected value of the risk. Ex ante, even if the probability of attack with WMD is low (e.g., 1\% per year), as long as the impact is serious (e.g., 500,000 deaths), then the expected value of the risk is potentially large (here, 5,000 deaths per year). If the probability or the impact were higher, the expected value could rise. And if (as seems to be the case) people are more upset by a mass disaster (such as the loss of 3,000 lives on 9/11) than by the sum of the same or greater number of individual deaths occurring separately (e.g., 40,000 automobile accidents dispersed over time and space), then the expected utility loss from a $1 \%$ chance of 500,000 deaths in a single attack would be even larger than the expected utility loss from 5,000 (or perhaps even 50,000) deaths occurring individually. A “catastrophe premium” would need to be added.

Thus if the wars in Afghanistan or Iraq (or other precautionary measures) would reduce the probability or impact of such an attack, they could be justified, despite the costs and countervailing risks. Ex ante, both wars were justified on this ground.

Ex post, the war in Afghanistan appears to have reduced the target risk of attack by Al Qaeda, ${ }^{116}$ though by how much and for how long is not easy to quantify. The real actors behind the 9/11 attacks, bin Laden and Al Qaeda, remain at large. Ex post, WMD have not been found in Iraq. ${ }^{117}$ Whatever WMD were thought to be in Iraq either did not exist or have escaped seizure. According to the US government's Iraq Survey Group, which searched for WMD capacity after the 2003 war, Iraq appears to have "essentially destroyed" its WMD capacity soon after the Gulf War of 1991 and closed its last biological weapons plant by $1996 .{ }^{118}$ US and UK intelligence reports of WMD in Iraq just before the 2003 war now appear to have been "overstated" and even "dead wrong." The question therefore remains whether the war in Iraq was really part of the war against terrorism or instead a costly distraction - whether the war in Iraq has made the world safer or less safe from terrorism. More generally, the question is whether the shift to a precautionary counterterrorism strategy is reducing overall risk. One could argue that even if WMD were not present in Iraq during 1996-2003, and even if Iraq had nothing to do with the 9/11 attacks and was not supporting Al Qaeda, Iraq had future plans to acquire WMD and had to be prevented from doing so. That is, if the probability or severity of an attack by Iraq would be likely to grow over time (for example, as Iraq obtained WMD or passed such weapons to terrorist groups), then an earlier invasion could be superior to waiting and attacking later, despite greater uncertainties. "The choice we have before us is we either go to war now or we will never go to war with Saddam until he chooses to use a nuclear weapon and he chooses the time and place. The question for me is not war or no war. It's a question of war now, when the costs may be significant, or war later when they may be unimaginable,” said Kenneth Pollack. ${ }^{119}$ Acting 
early to forestall a growing but uncertain risk is, as we have seen, a key tenet of the Precautionary Principle. But this argument would authorize highly precautionary strikes against countries with no current capacity to attack, based on conjecture about their future plans - going far beyond the doctrine of preemptive self-defense, and amid far greater uncertainties about the reduction in target risk to be achieved, if any.

Osama bin Laden is still at large. Many Al Qaeda leaders may have been captured or killed, but others may have taken their place. With no WMD yet found in Iraq, the target risk-reduction benefit now seems much smaller than had been anticipated before the war. The total effect even the direction of the effect - of the war on Al Qaeda's capacity to inflict harm (especially with WMD) remains highly uncertain. Perhaps we will be able to judge better in the future as new attacks do or do not occur, but it will still be very difficult to discern whether the rate or severity of those attacks would have been higher or lower in the absence of the war in Iraq. It would not be implausible to find that the war in Iraq yielded zero reduction in target risk of WMD attack on the US or Europe. It would also not be implausible to find (based on evidence yet to be uncovered) that it did yield some beneficial reduction in this target risk, or on the contrary that it increased this risk.

\section{$\underline{\text { Ancillary benefits }}$}

In addition to reducing the target risk, a policy intervention can also yield other unintended benefits such as the reduction of other coincident risks. ${ }^{120}$ Several kinds of ancillary benefits may arise from counterterrorism measures.

\section{Democracy and freeing the oppressed}

Liberating Afghanistan and Iraq from tyranny could help spread democracy there and in other countries. For example, some credit these two wars with not only putting Iraq on the road to democracy and freeing the two invaded countries from oppressive dictatorships, but also with spurring the elections in Palestine and the removal of Syrian forces from Lebanon. Others counter that internal events, chiefly the deaths of Yasser Arafat and Rafiq Hariri, were more important factors in Palestine and Lebanon. And they point to other countries with which the US has collaborated since 9/11 in the fight against terror, but where democracy is not flourishing, such as Pakistan, Uzbekistan and Egypt.

Davis et al. estimated that deposing Hussein would save 10,000 to 20,000 Iraqi civilian lives per year over 33 years (assuming a 3\% per year chance of the regime ending), extrapolating from a history of over 200,000 deaths caused by the Hussein regime and sanctions against it in the decade from 1991-2002, and over 400,000 deaths in the preceding decade caused by the IranIraq war and the Iraqi campaign against the Kurds. ${ }^{121}$ This assumes, however, that Hussein's killings would have continued at the same rate, and that the succeeding regime (or chaos) would cause no such deaths.

In any case, after WMD were not found in Iraq, the goals of liberating oppressed peoples and spreading democracy have become the Bush and Blair administrations' primary stated rationales 
for the war in Iraq, ${ }^{122}$ even though they were not emphasized by the administrations ex ante (at least not nearly as strongly as the WMD target risk). "[T] he example of political pluralism in one country will be emulated" in other authoritarian countries. ${ }^{123}$ "Furthermore, more democracies will mean greater stability, peaceful relations with neighbors and less terrorism.”" 24 Jervis argues that this ancillary benefit is the real justification for the war: "The war is hard to understand if the only objective was to disarm Saddam or even remove him from power. Even had the inflated estimates of his WMD capability been accurate, the danger was simply too remote to justify the effort. But if changing the Iraqi regime was expected to bring democracy and stability to the Middle East, discourage tyrants and energize reformers throughout the world ... then as part of a larger project, the war makes sense."125 Similarly, Michael Ignatieff believes that the ex post evaluation of the war in Iraq decades from now will turn on the claimed democracy benefit: "If democracy plants itself in Iraq and spreads throughout the Middle East, Bush will be remembered as a plain-speaking visionary. If Iraq fails, it will be his Vietnam, and nothing else will matter much about his time in office.” 126

That said, it remains unclear how significant this ancillary benefit will be. The Iraqi people have been liberated from Hussein's rule, but the insurgency continues, and it is not clear how long democracy will be sustainable in Iraq after US troops depart. Critics counter, among other things, that successful democracy cannot be imposed quickly by force from without, but requires cultivation by a domestic civil society (which in Iraq was depleted by the economic sanctions imposed in the 1990s); ${ }^{127}$ that human rights abuses attributed to US forces, such as at Abu Ghraib and Guantanamo, undermine US efforts to promote democracy and human rights in Iraq. They also argue that occupying Iraq to build democracy is a distraction from the war on terror, ties down US troops who would be better deployed to fight terror elsewhere, and exacerbates terror because it is the presence of US forces in Muslim countries that will incite terrorist attacks. ${ }^{128}$ Further, they claim that the transition from authoritarianism to democracy is likely to cause terrorism to increase first and decline only later. ${ }^{129}$

\section{Deterrence}

Attacking and deposing governments that support terrorism and WMD may deter other rogue states from potential violence. For example, soon after the war in Iraq, Libya admitted its nuclear weapons program and agreed to dismantle it. Bush administration officials credited the change in Libya to the example of Iraq. ${ }^{130}$ Perhaps Iran and North Korea will behave similarly. ${ }^{131}$ Others doubt that the war in Iraq is providing the impetus for these changes. They note that Muammar Qadafi had reportedly been trying to strike a deal since the Clinton administration, and the deal became possible only when an agreement was reached to make his son immune from prosecution in the Lockerbie bombing trial. They also argue that Iran and North Korea do not seem to be any more cooperative after the war in Iraq than before. Indeed, the war may have induced them to rush even faster to bolster their nuclear arsenals in order to deter a potential US strike.

\section{Diversion}

Perhaps the continuing violent insurgency in Iraq is actually a benefit, on the theory that it represents the diversion of Islamist terrorists away from other targets (such as the US homeland) to fighting in Iraq. The claim is that the Islamist radicals care most about Muslim control of 
Muslim countries, and less about attacking the US per se. Therefore the US invasion of Iraq has drawn thousands of foreign fighters (and Al Qaeda leader Abu Musab al Zarqawi) into Iraq to combat US troops, thereby diverting the terrorists from planning attacks elsewhere. It is unclear if there is serious evidence for this hypothesis. On the other hand, the continuing war in Iraq may be serving as a recruiting and training ground for new jihadists who will thereby be better equipped to attack the US and Europe in the future.

\section{Resilience}

Hardening targets and infrastructure against terror, such as by improving security, strengthening buildings, developing vaccines and improving response planning, could also help shield against risks unrelated to terrorism, such as crime, accidents, severe weather and pandemic disease. On the other hand, counterterrorism measures could divert public and private funding away from these purposes, undermining resilience. And there may be a tradeoff between public disclosure of risk information in order to reduce accidents (such as at chemicals facilities, under Clean Air Act section 112(r)), and withholding of this same information in order to avoid its use by terrorists to plan attacks.

\section{Transportation safety}

Aviation security systems could reduce highway traffic fatalities by enhancing the perception that air travel is safe, and by reducing the delay imposed by airport screening, both of which could increase air travel, reduce automobile travel, and thereby reduce highway accidents and deaths. But aviation security systems that increase delay (or other costs) would have the opposite effect, inducing greater highway travel and highway fatalities.

\section{$\underline{\text { Costs }}$}

Counterterrorism policies can be costly, in both out-of-pocket expenses and in social costs. This section focuses on financial outlays. Other adverse impacts of the war, such as military and civilian casualties, are discussed below in the section on Countervailing Risks.

Out of pocket expenses are significant. Between 2001 and 2004, the US budget for defense plus homeland security rose $50 \%$, from $\$ 354$ billion to $\$ 547$ billion. ${ }^{132}$ By contrast, as a union, EU members spend more than $€ 160$ billion on defense. Ex ante, the Bush administration was reluctant to name a number, but appeared to predict costs for the war in Iraq of under $\$ 100$ billion (former economic adviser Lawrence Lindsey was evidently fired for stating publicly that the costs would be between $\$ 100-\$ 200$ billion). Ex post, so far, the war in Iraq has cost the US federal budget well over $\$ 150$ billion. The costs have escalated as the insurgency has continued, more than a year after President Bush declared major military operations over while speaking in front of a banner reading "Mission Accomplished."

Before the war in Iraq, some economists attempted to estimate the full social costs. After reviewing preliminary studies by the House Budget Committee, the Congressional Budget Office 
and estimates from other major wars in US history, William Nordhaus developed the estimates in Figure 1, per decade (in billions of 2002 dollars).

Figure 1

Costs of the Iraq War: Nordhaus estimates ${ }^{133}$

\begin{tabular}{lll} 
Source of Cost & $\begin{array}{l}\text { Low scenario } \\
\text { (short and } \\
\text { favorable war) }\end{array}$ & $\begin{array}{l}\text { High scenario } \\
\text { (protracted and }\end{array}$ \\
\hline
\end{tabular}

Notes

Direct military spending $\quad \$ 50 \quad \$ 140$

[a]

Follow-on costs

Occupation and peacekeeping $\quad 75 \quad 500$

[b]

Reconstruction and nation-building

30

105

$[\mathrm{C}]$

Humanitarian assistance

1

10

Impact on oil markets

$-40$

778

[d]

Macroeconomic impact

$-17$

391

[e]

Total

$\$ 99$

$\$ 1,924$

[f]

Notes:

[a] Protracted conflict assumes that the monthly cost is 50\% greater than the CBO estimate and that the conflict lasts 8 months longer.

[b] The low and high numbers assume, respectively, peacekeeper costs of $\$ 200,000$ to $\$ 250,000$ per peacekeeper per year, with the numbers from 75,000 to 200,000, and for periods of 5 to 10 years.

[c] This includes, at the low end, reconstruction costs of \$30 billion and minimal nation-building costs. At the high end, it adds a "Marshall Plan for Iraq" as described in the text.

[d] These estimates refer to a full-employment economy. The high estimate is based on Perry's "worse" or middle case, which assumes a production decline of 7 million bpd offset by withdrawals from reserves of 2.5 million bpd. The "happy" case assumes that OPEC increases production by 0.67 million bpd in the five years after the end of hostilities and that production stays at the higher level. The sign is negative to indicate a benefit or negative cost.

[e] The macroeconomic impact excludes the full-employment impacts in [4] and includes only the first two years of a cyclical impact.

[f] These costs are the total for the decade following the conflict (e.g., 2003-2012). Negative numbers are benefits. 
Nordhaus's estimates ranged from about $\$ 100$ billion per decade in the "low" case (short war) to about \$2 trillion per decade in the "high" case (which assumes that "the war drags on, occupation is lengthy, nation-building is costly, the war destroys a large part of Iraq's oil infrastructure, there is lingering military and political resistance in the Islamic world to US occupation, and there are major adverse psychological reactions to the conflict)." ${ }^{134}$ Nordhaus was quick to agree that these two scenarios are not the only possible outcomes; they were offered to sketch the range of plausible costs.

The actual direct spending on the war may now exceed Nordhaus’s estimates. Combining military, occupation, reconstruction, and humanitarian spending, Nordhaus estimated direct expenses ranging from $\$ 156$ billion to $\$ 745$ billion per decade. But the total of such expenses from the beginning of the war in March 2003 through June 2005 (just over two years) is already over $\$ 150$ billion.

The effect of the war on the price of oil was a major component of both of Nordhaus's scenarios, accounting for almost half the net costs in each case. Nordhaus put the cost of oil in 2004 at about \$25 per barrel in the low scenario and about \$65 per barrel in the high scenario (drawing on work by George Perry). ${ }^{135}$ In fact, the price of oil in August 2004 was about $\$ 40$ to $\$ 45$ per barrel, about halfway between Nordhaus’s low scenario and his high scenario. By June 2005 the price had reached about $\$ 60$ per barrel. If this price increase is mostly due to the war in Iraq, then on Nordhaus's range of estimates it implies costs of at least $\$ 200$ billion or $\$ 300$ billion per decade (at least halfway between the savings of $\$ 40$ billion and costs of $\$ 778$ billion he forecast) in impacts on oil markets, and perhaps more in macroeconomic impacts.

A key uncertainty in Nordhaus's estimate is the duration of the occupation of Iraq and the intensity of the insurgency. The longer and more intense, the higher the costs. Ex ante, on February 7, 2003, Secretary Rumsfeld predicted the war would last between six days and six months. By June 26, 2005, he said the insurgency might last up to 12 years. Further, Nordhaus 
did not count the cost of military or civilian casualties due to the war. Nordhaus also emphasized that most ex ante estimates of the costs of war usually underestimate the actual costs. ${ }^{136}$ Meanwhile, Nordhaus' study did not attempt to quantify or compare the benefits of the war.

Davis et al. attempted a cost-benefit analysis of going to war in Iraq, compared to a policy of containment of Iraq with Hussein still in power. Their estimates are outlined in Figure 2.

\section{Figure 2}

Costs and benefits of the Iraq War: Davis et al. estimates ${ }^{137}$

30 years, 2003-2036 (US \$ billions)

Costs incurred

$\underline{\text { Costs avoided } \quad \text { Notes }}$

US \& Coalition

Expenses

125

380

Fatalities $\quad(\sim 5000)$

32.5

[a]

Homeland security expense

200

Another 9/11 attack damages

50

Iraq

\begin{tabular}{|c|c|}
\hline Fatalities $\quad(\sim 30,000)$ & 105 \\
\hline
\end{tabular}

Subtotals

125

630

$+35,000$ lives lost $\quad 137.5$

$+200,000+$ lives saved $700+$

[a]

Total

262.5

$1,330+$

[b], [c] 
Notes:

[a] Davis et al. did not monetize fatalities. For consistent comparison, these figures follow Wallsten \& Kosec (2005), assuming US

VSL $=\$ 6.5 \mathrm{~m}$, Iraq VSL $=\$ 3.5 \mathrm{~m}$ (based on income elasticity of VSL $=2.55$ )

[b] Unclear if Davis et al. discounted to NPV

[c] Omits: Macroeconomic (oil) costs, increased p(Terrorism), other CRs \& Abs.

On this basis, Davis et al. argued that the war would yield substantial net benefits, both to the US and to the Iraqi people, and both in financial and human terms. Note that the Davis et al. calculation did not include the ancillary benefits of spreading democracy elsewhere, or of deterring other rogue states. Nor did it even include the target risk reduction benefit of seizing Iraqi WMD - it counted only the avoided risk of additional low-technology terror attacks similar to 9/11. On the other hand, the Davis et al. estimate counted only out-of-pocket costs and did not appear to account for the effect of the war on oil prices and macroeconomic performance, which were the two largest items in Nordhaus's cost estimate. Nor did Davis et al. include the countervailing risks, which could increase the risk to the US of new terror attacks.

A more recent study by Wallsten \& Kosec conducts a mid-course benefit-cost evaluation of the war in Iraq. See Figure 3. 


\section{Figure 3}

Costs and benefits of the war: Wallsten and Kosec estimates ${ }^{138}$

2003-2005 (US \$ billions, “Mid” estimate)

Costs incurred

$\underline{\text { Costs avoided } \quad \underline{\text { Notes }}}$

US

Expenses

212

32

Fatalities

( 2000)

14

[a]

Injuries

$(\sim 14,000)$

18

[a]

Lost work

10

Other Coalition 
Expenses

Fatalities

Injuries

Iraq

Expenses

Fatalities

[a]
36

( 237) 1

2

20

$(\sim 30,000) \quad 106$

$(\sim 24,000)$

85
Injuries

Total
8 [a]

[a]

[a]

(Extrapolate same rates over 2005-2015: costs incurred \$576b, costs avoided \$313b.)

Notes:

[a] Assumes US VSL $=\$ 6.5 \mathrm{~m}$, Iraq VSL $=\$ 3.5 \mathrm{~m}$ (based on income elasticity of VSL $=0.55$ ). Injuries weighted by severity. Combines military and civilian casualties at same VSL. 5\% discount rate.

[b] Omits: Macroeconomic (oil) costs, Influence on p(Terrorism), other CRs \& ABs

They find that Davis et al. overstated the net benefits of the war. Wallsten and Kosec find that the direct costs of the Iraq war have exceeded the direct benefits by about a factor of two. They include both military expenditures and lives lost in the costs, and they include both the avoided costs of containing Saddam and the lives saved from the Saddam regime in the benefits.

Wallsten and Kosec did not quantify such other factors as the effect of the war on the risk of terrorist attack, the effect of democracy (or chaos) in Iraq, the deterrent effect on other rogue states (e.g. Libya, Iran, North Korea), the bogging down of US military in Iraq, or the effect of 
the war on oil prices and macroeconomy. It is not simple to compare these figures with those in Davis et al. (Fig. 2) because they cover different time periods and different types of impacts. For example, Davis et al. forecast $\$ 125$ billion in expenses and 35,000 deaths due to the war, which looks similar to the estimates in the Wallsten and Kosec analysis ( $\$ 268$ billion and 32,000 deaths), except that Davis et al. were forecasting these $\$ 125$ billion and 35,000 deaths to occur over 30 years, whereas Wallsten and Kosec are reporting that these amounts have already occurred in just the first two to three years of the war. On a comparable basis of costs and benefits per year, the benefits numbers are similar at about $\$ 30-50$ billion/year (largely because Wallsten and Kosec used Davis et al.’s forecast of 10,000 Iraqi deaths per year prevented by dethroning Saddam, although Wallsten and Kosec omit any number for the risk of future terrorism prevented whereas Davis et al. add \$50 billion for preventing another 9/11 type attack); but the costs estimates are quite different because Davis et al. appear to have underestimated the costs at only about $\$ 4$ billion/year (\$124 billion/30 years) and 1,000 deaths/year (35,000/30 years). Both studies omitted any estimate of the increased risk of terrorism due to the war, or numerous othe rancillary risks we identify here.

$\underline{\text { Increase in countervailing risks }}$

All risk management measures - whether to protect the world from toxics or terrorism - can have the perverse effect of increasing other risks and, potentially, of creating a more dangerous world. ${ }^{139}$ There can be real risks to precaution, whether military or regulatory, but health and safety risks as well. Such "risk-risk tradeoffs" are pervasive in human decision-making. ${ }^{140}$ Graham and Wiener argue that decision-makers should evaluate the expected consequences and weigh the tradeoffs; and they should seek "risk-superior" strategies that reduce multiple risks in concert rather than trading one risk for another. ${ }^{141}$

The use of foreign policy and military force to reduce risks such as terrorism and WMD is not immune to risk-risk tradeoffs. ${ }^{142}$ Indeed, the history of warfare is replete with instances in which military strategies proved ineffectual or worse, counterproductive - what Barbara Tuchman has called the "March of Folly." 143 Military intervention can fail or backfire. Even when military actions succeed in their operational aims, they typically cause some "collateral damage" to civilians.

Consider a few examples: raiding buildings where terrorists have taken hostages can kill both combatants and hostages, as occurred in the Moscow theatre in 2002 and at the school in Beslan, Russia in September 2004. Bombing terrorist camps and military facilities, even with precisionguided munitions, can kill nearby civilians. Giving airline pilots guns to stop terrorists may lead to in-flight accidents, theft or misuse. Restrictions on suspected terrorists' access to the country can also impinge on innocent immigrants' civil liberties. ${ }^{144}$ Controlling access to information on pathogens and materials to prevent bioterrorism can increase the impact of natural disease outbreaks. $^{145}$

Moreover, terrorism is a dynamic strategic risk. Because terrorists are strategic actors who respond to countermeasures, assessing the full consequences of a counterterrorism strategy must include attention to such responses. For example, hardening some targets against attack (if such defenses are observable) can induce terrorists to shift their attacks to other targets. ${ }^{146}$ Military 
strikes against terrorist camps can incur reprisals by those attacked and "blow-back" by spurring the recruitment of even more terrorists. ${ }^{147}$ Historically, there is reason to believe that counterterrorism measures have influenced terrorists to change their tactics. When metal detectors were installed at airports, terrorists found other ways to attack planes. When governments protected embassies with concrete barriers, terrorists turned to larger explosives. The attack on multiple trains in Madrid in March 2004 and London in July 2005 may reflect terrorists' understanding that airplanes were by then relatively harder targets. In another setting, when governments begin profiling a particular type of suspect, terrorists may recruit another type. For example, airline screening for particular passenger attributes may yield false negatives as terrorists deploy operatives selected to evade the profile (or switch to other targets such as trains or ports), and also false positives that snare innocent travelers and condition inspectors to relax their vigilance. Similarly, the official profile of a typical terrorist developed by the US Department of Homeland Security to scrutinize visa applicants and resident aliens applies only to men. That profile was developed before the advent of Islamist chat rooms recruiting operatives for a global jihad, before the war in Iraq increased anti-US sentiment worldwide, and before women started serving as suicide bombers for Islamist terrorist organizations (and before the summer 2004 bombings by "Black Widow" female terrorists from Chechnya). The lack of scrutiny of women entering the US, and the significantly greater focus on men from Islamic countries, may lead Al Qaeda to turn increasingly to women and other recruits who do not fit the standard profile of a Middle Eastern male. According to intelligence assessments cited in the press, the Al Qaeda movement is seeking recruits all over the world - in Western prisons and inner cities, among Hispanic Americans and among French converts to Islam. Through Internet communications, it is urging individuals to create their own cells and carry out their own strikes, without necessarily joining existing militant organizations. And it is recruiting women. ${ }^{148}$

Policy advocates, and the risk analyses they conduct, too often assume a simple one-way relationship between policy interventions and the resulting change in risk, neglecting responsive behavior by the regulated actors. But risk analysis should be addressing a broader spectrum, from stochastic risks whose sources do not react to preventive measures (e.g., earthquakes and asteroids), to dynamic risks whose sources are strategic or responsive risk agents who attempt to circumvent or retaliate against preventive measures (e.g., pathogens, terrorists and pollution in the longer term as even law-abiding firms react strategically to regulations).

In short, every protective intervention - military, regulatory or medical - also runs the risk of causing new harms. Precautionary regulation can transfer risks to new populations, substitute new risks for old ones in the same population, or both. ${ }^{149}$ Assessing the impact of regulatory action requires a holistic assessment of the multi-risk portfolio affected by each intervention. ${ }^{150}$ These are the same questions to ask about both regulatory policies and counterterrorism actions alike. A consistent approach to precaution and government power requires attention to the countervailing risks of both environmental regulation and counterterrorism.

One avowed purpose of the Precautionary Principle is to empower government to be able to intervene before risks become catastrophes. ${ }^{151}$ Analysis of risk-risk tradeoffs is a sensible check on excessive precaution and on excessive or narrow-minded exercise of government power. ${ }^{152}$ When precaution is invoked by government to wage war against terrorism, that too may pose countervailing risks, and analysis of risk-risk tradeoffs is again the sensible response to check 
excessive or narrow-minded exercise of government power - in this case, immense power. Liberals who dislike force and aggression, and conservatives who are suspicious of government power, should both agree on the need for risk-risk tradeoff analysis in either of these cases.

It is crucial to recognize that there can be countervailing risks of counterterrorism policies even if the claims about WMD and other terrorist activities were true positive forecasts. The issue is the expected consequences of the policy choice, not just the existence of the target risk. It is an error to assume, as the media and the public and many experts seem to do, that the question to be answered is only whether the risk is "real" or not, i.e. whether there are WMD in Iraq (or an IraqAl Qaeda link). The assumption behind this posture is that if the answer is no (false positive), intervention is unwarranted, but if the answer is yes (true positive), intervention is warranted. But because there are also costs and countervailing risks of intervening, even a true positive is not sufficient to warrant intervention. Intervention must still be evaluated in terms of its overall risk consequences. At the same time, a definitive true positive is also not necessary to warrant intervention: even if the answer is "we're not sure” (uncertainty), there can still be a warrant for intervention, because the uncertainty-weighted (expected value) risk reduction to be gained from the intervention might still be large enough to outweigh its costs and countervailing risks.

The same error is made regarding environmental risks such as climate change: the public debate and some expert debate is fixated on whether global warming is "real" or not, when decision analysis teaches that even an uncertain risk could warrant precaution (true positive not necessary), and also that even a highly certain risk might not warrant precaution, if the costs and countervailing risks are too large relative to the effectiveness of the policy (true positive not sufficient). The issue is the expected consequences of the policy choice, not the reality or improbability of the target risk.

The war in Iraq could increase a variety of countervailing risks. Here we identify several.

\section{Collateral damage: civilian deaths}

Data on civilian and military deaths in war are not easy to find, and those data that are available may be disputed or unreliable. In Figure 4 we have collected the available range of estimates for several wars involving the US during the past century.

\section{Figure 4}

Deaths in selected wars

(Compiled from the sources indicated by Wiener and Cromer)

\begin{tabular}{|l|l|l|l|l|l|l|}
\hline $\begin{array}{l}\text { War and } \\
\text { year } \\
\text { started }\end{array}$ & US military & $\begin{array}{l}\text { Enemy } \\
\text { military }\end{array}$ & $\begin{array}{l}\text { Total } \\
\text { military }\end{array}$ & Civilian & $\begin{array}{l}\text { Civilian / } \\
\text { US } \\
\text { military }\end{array}$ & $\begin{array}{l}\text { Civilian / } \\
\text { total } \\
\text { military }\end{array}$ \\
\hline
\end{tabular}




\begin{tabular}{|c|c|c|c|c|c|c|}
\hline $\begin{array}{l}\text { Iraq - } \\
2003\end{array}$ & $\begin{array}{l}1,978 \text { plus } 199 \\
\text { other coalition }^{1}\end{array}$ & $\begin{array}{l}\sim 5,000 \text { to } \\
6,400\end{array}$ & $\begin{array}{l}7,000- \\
8,400\end{array}$ & $\begin{array}{l}26,568 \text { to } \\
29,922^{2} \text { or } \\
100,000^{3}\end{array}$ & $\begin{array}{l}\sim 13 \text { to } \\
\sim 52\end{array}$ & $\sim 3$ to $\sim 12.5$ \\
\hline $\begin{array}{l}\text { Afghanist } \\
\text { an }-2001\end{array}$ & $192^{4}$ & $?$ & $?$ & $3,300^{5}$ & $\sim 17$ & ? \\
\hline $\begin{array}{l}\text { Gulf War } \\
-1991\end{array}$ & $293^{6}$ & $\begin{array}{l}\sim 35,000^{7} \\
\text { to } \\
40,000^{8}\end{array}$ & $\sim 40,000$ & $\begin{array}{l}\text { 13,000 } \\
\text { directly plus } \\
\sim 125,000^{9}\end{array}$ & $\sim 471$ & $\sim 3.5$ \\
\hline $\begin{array}{l}\text { Vietnam } \\
-1962\end{array}$ & $\begin{array}{l}\text { 58,168 }{ }^{10} \text { plus } \\
223,748 \text { South } \\
\text { Vietnamese } \\
\text { and 5,282 } \\
\text { other }^{11}\end{array}$ & $\begin{array}{l}1,100,00 \\
0^{12}\end{array}$ & $1,387,198$ & $\begin{array}{l}\text { 4,000,000 (2 } \\
\text { million each } \\
\text { in North and } \\
\text { South) }\end{array}$ & $\begin{array}{l}69 \text { (US } \\
\text { only); } \\
14 \text { (US + } \\
\text { SV) }\end{array}$ & $\sim 3$ \\
\hline $\begin{array}{l}\text { World } \\
\text { War II - } \\
1939\end{array}$ & 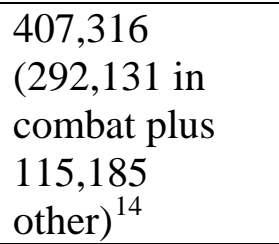 & $\begin{array}{l}5,466,00 \\
0^{15}\end{array}$ & $\begin{array}{l}23,289,00 \\
0^{16}\end{array}$ & $30,755,000^{17}$ & $\begin{array}{l}75 \\
\end{array}$ & $\begin{array}{l}1.3 \\
\end{array}$ \\
\hline $\begin{array}{l}\text { World } \\
\text { War I- } \\
1914\end{array}$ & $\begin{array}{l}116,708 \\
(53,513 \text { in } \\
\text { combat plus } \\
63,195 \text { other })^{18}\end{array}$ & $\begin{array}{l}3,200,0 \\
00 \text { to } \\
5,600,00 \\
0^{19}\end{array}$ & $\begin{array}{l}8,538,315 \\
20 \text { or } \\
\text { o,364,712 } \\
\text { to }\end{array}$ & $\begin{array}{l}\sim 5,000,000 \text { to } \\
13,000,000^{22}\end{array}$ & $\begin{array}{l}43 \text { to } \\
111\end{array}$ & $\sim 0.4$ to 1.6 \\
\hline
\end{tabular}

${ }^{1}$ From www.icasualties.org/oif accessed October 18, 2005. (US Military wounded: 14,641 official, see ibid.; 15,000-38,000 estimated at http://www.antiwar.com/casualties, accessed October 18, 2005.)

${ }^{2}$ From http://www.iraqbodycount.net accessed October 18, 2005.

${ }^{3}$ Les Roberts et al., "Mortality before and after the 2003 invasion of Iraq: cluster sample survey,” 364 The Lancet 1857-1864,

Oct. 29, 2004, available at http://www.thelancet.com/journals/lancet/article/PIIS0140673604174412/fulltext .

${ }^{4}$ From http://www.antiwar.com/casualties accessed June 27, 2005.

${ }^{5}$ From http://pubpages.unh.edu/ mwherold/ accessed June 27, 2005.

6 Al Nofi, "Statistical Summary: America’s Major Wars," last modified June 13, 2001, at http://www.cwc.lsu.edu/cwc/other/stats/warcost.htm , accessed June 27, 2005 (based on "Principal Wars in which the US Participated: US Military Personnel Serving and Casualties,” Washington Headquarters Services, Directorate for Information Operations and Reports, U.S. Department of Defense Records, Table 2-23).

7 Kenneth Pollack, The Threatening Storm: The Case for Invading Iraq, New York: Random House, 2002: 139.

8 From http://www.businessweek.com/bwdaily/dnflash/feb2003/nf2003026_0167_db052.htm, accessed June 27, 2005.

${ }^{9}$ From http://www.businessweek.com/bwdaily/dnflash/feb2003/nf2003026 0167 db052.htm accessed June 27, 2005. The

$\sim 125,000$ are post-war deaths were due to destruction of the country's infrastructure, water, electricity, and health care. The 138,000 civilians do not include 30,000 Kurdish and Shiite rebels killed by Saddam Hussein.

10 Nofi, supra. See also http://www.eiis.net/cmart/vietwarstats.html (counting 58,202).

11 From http://www.rjsmith.com/kia_tbl.html , accessed June 27, 2005.

12 From http://www.rjsmith.com/kia_tbl.html, accessed June 27, 2005.

13 From http://www.rjsmith.com/kia_tbl.html, accessed June 27, 2005.

14 Nofi, supra. Combat deaths include troops killed in action or dead of wounds. Other includes deaths from disease, privation, accidents, and losses among prisoners of war. Figures do not include deaths of other Allied forces.

15 Geoff Price, "Casualties of War-Putting American Casualties in Perspective”, November 3, 2003, at http://www.rationalrevolution.net/articles/casualties of war.htm , accessed June 27, 2005.

${ }_{16}$ Price, supra. Here Price appears to count only combat deaths, not others due to disease, privation, accidents, etc. (at least for the US, for which he counts 295,000 military deaths).

${ }^{17}$ Price, supra.

${ }^{18}$ Nofi, supra. Price, supra, counts 126,000; here Price appears to count both combat and other deaths. Figures do not include deaths of other Allied forces.

${ }^{19}$ From http://users.erols.com/mwhite28/warstat1.htm accessed June 27, 2005.

20 Price, supra. 
\begin{tabular}{|l|l|l|l|l|l|l|}
\hline & & & $12,599,00$ & & & \\
\hline
\end{tabular}

In the Afghanistan and Iraq wars, ex ante, US officials predicted that US troops would be greeted as liberators and the wars could last days. Ex post, these two wars have lasted longer and have killed thousands so far, including about 2,000 US soldiers combined. The US and UK militaries have not kept, or have not disclosed, counts of civilian deaths in Afghanistan and Iraq. Private analysts have attempted to keep such data. Through May 2003, civilian deaths from the war in Afghanistan were roughly 3,300, with the vast majority occurring in the first four months of war from October 2001-February 2002, according to an accounting by University of New Hampshire economist Marc Herold. ${ }^{153}$ From March 2003 through June 2005, civilian deaths from the Iraq war were roughly 24,000, according to the website http://www.iraqbodycount.net/ maintained by independent researchers drawing on Herold's methodology. But an estimate by public health researchers from John Hopkins University and their colleagues, based on surveys of a sample of households in Iraq and published in the peer-reviewed medical journal The Lancet, estimated that the number of civilian deaths resulting from the Iraq war (through October 2004, principally due to air strikes) was closer to 100,000 or more. ${ }^{154}$

At the same time, the extent of collateral damage caused by US forces appears to be declining over time, probably because of increased use of precision weapons technologies. As indicated in Figure 4, the ratio of civilian deaths per US military death appears to have steadily declined, from 43 to 111 in World War I, 75 in World War II, 14 to 69 in Vietnam, 17 in Afghanistan and 13 in the Iraq War (using the lower figure of 24,000 civilian deaths), but it may have increased to 53 (using the higher figure of 100,000 civilian deaths). The possible increase in the ratio in the Iraq war, despite precision weapons, may be associated with more air strikes occurring in densely populated urban areas. (The outlier figure of 471 civilian deaths per US military death in the 1991 Gulf War is the result of the very small number of US military deaths and the roughly 125,000 deaths due to the post-war chaos within Iraq, for which causation is difficult to attribute; omitting those 125,000 would yield a ratio of 44, in line with the declining trend from World War I through the Iraq War). Some observers agree that precision weaponry is shielding civilians:

“'If you talk to the Red Cross or most other observers, you'll find that [US forces] did a rather good job of avoiding or minimizing collateral damage' in both Iraq and Afghanistan, says Robert Goldman, who specializes in human rights and armed conflict at American University's Washington College of Law. (Civilian casualties in Afghanistan are as difficult to calculate as those in Iraq.) This was not the case in previous wars. In World War II, tens of thousands of civilians were killed in single attacks. Mussolini terror-bombed Ethiopia; Nazi Germany indiscriminately bombed London; and the Allies firebombed Dresden and other German cities. Tokyo was firebombed, and the US dropped atom bombs on two Japanese cities. 'We've certainly changed our practices since World War II everyone has - where the cities themselves were seen as targets,' says Prof. Goldman. Yet, in some ways, civilian casualties increasingly have become part of war - certainly part of

\footnotetext{
${ }^{21}$ From http://users.erols.com/mwhite28/warstat1.htm accessed June 27, 2005.

22 From http://users.erols.com/mwhite28/warstat1.htm accessed June 27, 2005.
} 
the Pentagon's planning for what's called 'asymmetrical war' fought against terrorist cells, insurgencies and stateless organizations like Al Qaeda.”"155

It is interesting to note, however, that the ratio of civilian deaths to total military deaths (the last column in Figure 4) appears not to have declined at all over time (remaining at about 3), and may even be rising. The ratio of total military deaths to US military deaths fell from 85 in WWI (where the US entered the war long after the other great powers) to 57 in WWII (where much of the bloodiest fighting was between countries other than the US) to 24 in Vietnam, then rose to 137 in the Gulf War (where US casualties were very low), and then fell to 4 in Iraq.

\section{Blow-back: increased terrorism}

The invasion and occupation of Iraq could increase terrorist recruiting - as feared by Secretary Rumsfeld, quoted above - by causing anger and humiliation among a wide swath of the Iraqi people and Muslims generally. The idea (accurate or not) that the US is engaged in a crusade against the Islamic world is a critical component of the Islamist nihilists' worldview, and spreading this idea is critical to their success. The unprovoked attack on Iraq, not aimed at $\mathrm{Al}$ Qaeda and followed by the US occupation of a Muslim country, accompanied by occasional religious rhetoric from US generals and officials about a "crusade" to "rid the world of evil," may give credence to this view and increase the flow of recruits to radical Islamist terror cells. ${ }^{156}$ Many advocates of the war on terrorism have criticized the invasion of Iraq as likely to strengthen terrorism by expanding the ranks of new recruits to Al Qaeda, such as Pillar, ${ }^{157}$ Michael Scheuer, ${ }^{158}$ James Fallows, ${ }^{159}$ Richard Clarke, ${ }^{160}$ Joseph Cirincione ${ }^{161}$ and Christopher Adams. ${ }^{162}$ Cirincione et al. state: "It was almost inevitable that a US victory would add to the sense of cultural, ethnic and religious humiliation that is known to be a prime motivator of $\mathrm{Al}$ Qaeda-type terrorists. It was widely predicted by experts beforehand that the war would boost recruitment to this network..." 163 It bears noting that there is no weakness or disloyalty in recognizing that an aggressive precautionary stance may be counterproductive. As Tuchman observes, refusing to recognize such consequences is classic military folly. ${ }^{164}$ It is more loyal to our troops and the nation to deploy our forces effectively, not perversely. Israel, staunchly antiterrorist, recently chose to end its own practice of demolishing the homes of Palestinian militants' relatives because Israeli analysts found that this policy inspired more terrorism, not less. ${ }^{165}$

The flow of new terrorist recruits depends on motivations that counterterrorism policy can influence. A key factor appears to be the sense of humiliation among Muslim men. ${ }^{166}$ The purpose of fighting the new world order and US imperialism, in the view of Zawahiri, bin Laden's second in command, is to restore the dignity of humiliated youth. This idea is similar to Franz Fanon's radical claim that violence is a "cleansing force" that frees the oppressed youth from his "inferiority complex, despair and inaction,” making him fearless and restoring his selfrespect. ${ }^{167}$ It is in the context of these kinds of radical beliefs that the war in Iraq, and the horrific images of US soldiers humiliating and torturing Iraqi prisoners at Abu Ghraib or the allegations of US interrogators desecrating the Koran at Guantanamo, may be so inflammatory and counterproductive. 
Many observers of diverse political stripes worry about the impact of the war on support for the US in the Islamic world. "Listening to the neoconservatives, Bush invaded Iraq, united the Arab world against us, isolated us from Europe and fulfilled to the letter bin Laden's prophecy as to what we were about. We won the war in three weeks - and we may have lost the Islamic world for a generation,” Pat Buchanan warned. ${ }^{168}$ Former Vice President Gore has made the same argument. ${ }^{169}$

Intelligence agencies warn that the war was used to good effect by Al Qaeda in increasing its recruitment of new members. Pillar argues that the invasion has also made the terror network harder to combat by dispersing it worldwide, and that the capture or killing of bin Laden will spark an ecstatic popular reaction followed by relaxation, while the terror network will continue to spread and subdivide unabated. ${ }^{170}$ In the near term, Europeans and Asians are more likely to suffer the consequences because, for reasons not yet fully understood (perhaps relating to the degree or lack of success and assimilation in mainstream society), a greater proportion of Muslims in Europe and Asia are joining the global jihadi movement, and those groups are attacking Europe and Asia, not the US, at least for now. Moreover, the presence of foreign occupying troops has been identified as an important motivating factor in recruiting suicide bombers (in both secular and religious movements) against the occupier's troops and home country. ${ }^{171}$

Shackling US military capacity

The invasion and occupation of Iraq, particularly because it is lasting so much longer than predicted ex ante, may impinge on US military capabilities and thus reduce US capacity to combat terrorism and other threats:

- Distraction from greater threats. The extended attention and resource commitment to Iraq may be distracting the US from Al Qaeda in other countries such as Afghanistan, and from other rogue states, such as Iran and North Korea, that are much closer to deploying WMD than Iraq was. ${ }^{172}$ As the US gets bogged down in Iraq (which proved not to have WMD), it may be forfeiting the ability to address the target risk of WMD where it really exists, such as in Iran and North Korea and perhaps elsewhere.

- Reduced recruiting. The extended war in Iraq, and policies, such as "stop-loss" to prevent soldiers from returning home after their originally-agreed service duty is completed, are sharply reducing US Army recruiting rates. ${ }^{173}$ This deficit may undermine the ability of the US to fight the next (more important) war.

- Emboldened adversaries. The war may be showing the insurgents and the world that the superpower US military can be held at bay for months, thereby inspiring additional groups to be confrontational.

- Under-reaction next time. The belief (accurate or not) that US and UK claims of WMD in Iraq were a false positive, or "crying wolf," may lead other countries to disbelieve the US and UK the next time they assert a WMD threat. Yet the next time may be tragically true (just as the wolf ultimately ate the sheep when no one would believe the boy). The 
present false positive and overreaction may yield a future under-reaction, thereby incurring just the risk of a WMD attack on the US or Europe that the precautionary Bush administration strategy is intended to prevent.

- Dividing NATO. The war in Iraq has divided the NATO alliance, at least temporarily. The US, UK, Poland, Italy and Spain joined the war, but France, Germany, Russia and others opposed it. Spain later switched parties and withdrew. If the Western alliance remains divided, that may do more to undermine future ability to combat terrorism and WMD than the war in Iraq has done (if any) to advance that goal.

- Tempting others to preempt. The UN's High-Level Panel in 2004 argued that authorizing unilateral preventive war is an invitation for all to do so. Setting the precedent of unilateral preventive war may induce fear of surprise attack, tempting others to attack first lest they be attacked. The result may be more frequent wars among other states, some of which entangle the US; and the possibility that a country like North Korea might strike the US first, not expecting strategic victory, but in the hopes of decapitating the US government. The Brookings Institute wrote that preemptive war "[s]trategy fails to acknowledge that a preemptive attack could precipitate the very attacks it seeks to prevent. An obvious danger is that the rogue state will use its weapons of mass destruction before it loses them - or deliberately give them to a group that will.”174

Each of these is a serious problem; taken together they suggest that, even if the war in Iraq has not increased terrorist recruiting rates or otherwise assisted terrorists, it may have increased the future risk to the US and Europe of a successful terrorist attack with WMD.

\section{Dissemination of WMD and weapons-usable materials}

One of the gravest countervailing dangers in going to war in Iraq was the risk that WMD materials and expertise would be disseminated rather than destroyed. Indeed, attacking Iraq, without protecting its borders, may well have made it more likely that WMD components and expertise would end up in the hands of terrorists. Ironically, this countervailing danger would be higher if Iraq really did possess the WMD that the Bush and Blair administrations argued it had and if Hussein really were prepared to share his WMD with terrorists.

Although these assertions now appear to have been false, some dissemination of materials and expertise appears to have occurred. The buildup to the US/UK invasion took several months, allowing ample time to hide or relocate WMD. After the war, no WMD were found, but Iraqi authorities informed the IAEA that 380 tons of high explosives under IAEA seal had been stolen - explosives that the IAEA had specifically warned the US to guard, apparently in vain. ${ }^{175}$ The IAEA reported to the UN Security Council that satellite imagery has shown many instances of the dismantlement of entire buildings that housed precision equipment as well as the removal of equipment and materials. Biological materials may have been stolen as well, according to a report co-authored by Jessica Matthews, who visited Iraq to investigate; enough material to produce a "dirty bomb" was stolen. ${ }^{176}$ Once scientists know how to grow and disseminate biological agents effectively, new stockpiles can be rapidly rebuilt. Perhaps some of Hussein's 
weaponeers, displaced or disaffected by the invasion and overthrow, provided their expertise to our terrorist enemies.

Moreover, the strategy of preemption (or preventive war) could itself induce rogue states to use or pass on their nascent WMD. "An obvious danger is that the rogue state will ... deliberately give [its WMD] to groups that will [use them]. A less obvious danger is that terrorists will be able to use the chaos that accompanies war to buy or steal weapons of mass destruction,” according to scholars at the Brookings Institution. ${ }^{177}$

\section{Applying risk analysis to counterterrorism: a new institutional mechanism}

The shift in national security strategy, from containment to preemption of imminent threats to precaution against uncertain future threats (preventive war), emphasizes the need for ex ante full portfolio analysis of risks, benefits and costs. Precaution is a highly risky strategy because it strikes first, while the target risk is highly uncertain, and thus may strike the wrong target (a false positive) or create countervailing risks, or both. ${ }^{178}$ A primary lesson learned in the regulation of health and environmental risks is that all risk management interventions, and especially precautionary measures, need to be evaluated with ex ante analysis of risks, benefits and costs to avoid serious policy errors, ${ }^{179}$ and supplemented with ex post review to adjust policy in light of updated information and to validate the ex ante estimates. The Bush administration's chief regulatory official, former Harvard professor John D. Graham, has been an outspoken and effective advocate of rigorous review of the risks, benefits and costs of proposed regulations, and a critic of the Precautionary Principle. ${ }^{180}$

Ex ante risk analyses often overstate, understate or omit key factors. Ex post analyses can be useful in identifying such errors and thus improving the framework used for future ex ante analyses. As detailed above, before the war in Iraq, the US and UK government estimates overstated the target risk reduction benefits from disarming supposed Iraqi WMD, understated the costs, omitted important countervailing risks and (later) switched to ancillary benefits to justify the war (such as removing Hussein and democratizing Iraq and the Middle East). Private experts' ex ante estimates also erred: Nordhaus omitted benefits and key countervailing risks, and Davis et al. omitted some benefits, some costs and key countervailing risks. We have compiled an ex post risk analysis of the war in Iraq that attempts to furnish a more complete set of factors to consider and weigh, and offers a basis for evaluating the ex ante analyses.

Therefore, we argue that better ex ante analysis of counterterrorism requires a more systematic approach to full portfolio risk analysis, and the creation of a new risk analysis function for the US and other governments to undertake and review such analyses.

The same analytic approach applied to other precautionary health protection interventions should be applied to such measures to reduce the risk of terrorism. Advocates of risk analysis in the regulatory arena should immediately see its value in shaping smarter counterterrorism policies, avoiding mistakes and perverse results, and allocating scarce resources efficiently. Indeed, it is particularly the conservative advocates of risk and cost-benefit analysis as a check on government power who should see its need in the counterterrorism arena, even as they champion the war on terrorism. Meanwhile, critics of risk analysis in the health and environmental 
regulatory arena should see that its application to counterterrorism measures would be a valuable expansion of risk analysis to apply more evenhandedly across all government operations (rather than being a special check on health and environmental policies alone). They may also see it as supportive of their own concerns about precautionary counterterrorism actions, such as the war in Iraq.

The primary objection to ex ante risk analysis of precautionary counterterrorism measures will come from advocates of preventive war in the age of non-state actors wielding WMD. These advocates, including those who adopted the new US National Security Strategy in 2002 and steered the preventive war in Iraq, will fear that such analysis will delay needed actions that must be taken quickly. This is, of course, precisely the same objection made by advocates of precaution in the health and environmental arena: that risks are upon us, delay is fatal, and ex ante review means "paralysis by analysis.” The same answers can be given to respond to both concerns. First, if the analysis improves the decision and thereby avoids major mistakes, costs, countervailing risks and perverse folly, the analysis will be highly worthwhile. The entire point is that hasty precaution can be worse than waiting to analyze the problem more fully. Second, by improving the policy choice, the analysis can actually save time down the line, when a poorly designed policy would be overhauled or even abandoned in light of its costly or perverse consequences and the attendant public disaffection or backlash. The absence of WMD in Iraq, the seemingly endless insurgency bogging down US forces and diverting our attention from more urgent risks in Iran and North Korea, and the increasing disapproval by the US public of the war in Iraq are illustrative; ${ }^{181}$ better ex ante analysis might have avoided this trap. Third, analysis can be accelerated and streamlined to frame decisions more quickly, while still performing the cognitive framing function that helps avoid neglect of important consequences. It can even be undertaken in advance, of multiple hypothetical situations and scenarios, and then updated quickly when the actual need arises. Fourth, the war in Iraq was not undertaken instantly; indeed the Bush and Blair administrations are at pains to insist that they took months to attempt diplomacy and UN resolutions before deciding on war as a last resort, so there would clearly have been time for a more systematic risk analysis in at least that case. Fifth, it is true that excessive analysis could mean unwarranted delay, but this too should be subject to a balancing test: additional analysis should be undertaken where its benefits in improved policy outweigh its costs in delaying reduction of the target risk, and not where the reverse is true. Thus, requirements for analysis should be stronger where the consequences of error are higher, and streamlined where the decision is more urgent.

A different objection will be that not all consequences of counterterrorism measures can be quantified or monetized. Deaths and injuries to soldiers and civilians can be counted, but monetizing them is more controversial. Restrictions on privacy and mobility may be harder to quantify. Probabilities and responsive strategies may be difficult to calculate. The same kinds of questions arise during analysis of health and environmental regulations. As Weeks notes, in the military context (as in the environmental context), "the difficulty of calculating costs and benefits does not mean that we gain nothing from this approach... Understanding the costbenefit structure ... should prove a useful exercise for decision makers now and in the future.”182 These issues can be handled by treating some factors qualitatively, and by improving methods of quantification. The crucial point is to help and force the decision maker to recognize the full consequences; it is a cognitive more than a mathematical exercise. ${ }^{183}$ 
Indeed, the need for careful analysis of the risks, benefits and costs of counterterrorism measures seems to be widely agreed. Secretary of Defense Rumsfeld worried to the 9/11 Commission that "the cost-benefit ratio" needs to favor the US but may not. ${ }^{184}$ Yoo has argued that military selfdefense (authorized under the UN Charter) needs to be understood in cost-benefit terms, ${ }^{185}$ which implies that proposed preventive wars should be carefully evaluated for their benefits, costs and risks. Weeks has argued forcefully that the crucial challenge for future military success is not new hardware technology but better decision making, informed by full analyses of risks, benefits and costs; he calls for the regular application of economic analysis to military decisions. ${ }^{186}$ Mel Martinez, US Senator (R-Florida) and former cabinet secretary in the Bush administration, commented on the pitfalls in US counterterror strategies: "At some point you wonder about the cost-benefit ratio," he told The Economist. ${ }^{187}$ Senator Martinez is quite right, and the time to start "wondering," to demand analysis of the benefits and costs, is before the key strategic decisions are made, not only two or three years afterward.

To make such ex ante review effective, an expert body capable of conducting serious analyses (and not beholden to the missions of the agencies it is reviewing) needs to be charged by the president with the task of policy review and the authority to check unwarranted policies and encourage desirable policies. In the health and environmental regulatory system, this function is played by the Office of Information and Regulatory Affairs (OIRA) in the White House Office of Management and Budget (OMB), which reviews Regulatory Impact Analyses (RIAs) and has the power to "return" proposed regulations whose RIAs are unsatisfactory. (A similar system of RIAs is currently being adopted by the EU under its Better Regulation initiative.) ${ }^{188}$ OIRA has performed this function since President Ronald Reagan issued Executive Order 12291, requiring cost-benefit review of all new regulations, in 1981; but the requirement to evaluate the benefits and costs of regulation has been a bipartisan commitment of every president since the substantial expansion of the regulatory state after 1970, including President Jimmy Carter's Executive Order 12044 requiring economic analysis of new regulations, and President Clinton's Executive Order 12866 in 1993 reconfirming the cost-benefit review requirements of the Reagan order and indeed strengthening this process. (The current Bush administration has retained Executive Order 12866, and OIRA continues to review regulations under its terms.) As noted above, although some advocates of the Precautionary Principle see it as opposed to regulatory impact analysis on cost-benefit criteria, others see the two as potentially compatible once precaution is translated into appropriate additional weights to be added when calculating the impacts of catastrophic risks. $^{189}$

Yet such analysis of counterterrorism measures does not appear to be required or even typically practiced. There appears to be no Presidential Executive Order or Decision Directive (at least none publicly available), analogous to Executive Order 12866 or its predecessors requiring the military and intelligence agencies to conduct such reviews. There seems to be no institutionalized process of White House review, analogous to OIRA review of regulations, for counterterrorism measures. "There is no evidence that the President and those closest to him ever talked systematically about the 'opportunity costs' and tradeoffs in their decision to invade Iraq," notes Fallows. ${ }^{190}$ There is the President's Homeland Security Advisory Council (PHSAC), created by Executive Order on March 19, 2002, ${ }^{191}$ which is one institutional mechanism by which the president could get advice on counterterrorism actions and their consequences; but it 
appears not to have the expert analytic staff that OIRA does; and it is focused on domestic/homeland policies, not foreign/military policies. The Defense Department has had Instruction 7041.3 (Nov. 7, 1995) calling for “Economic Analysis for Decision Making” and establishing a Defense Economic Analysis Council, but those analyses are limited to procurement and other federal expenditure decisions and do not appear to apply to counterterrorism actions such as military interventions. The crucial role of systematic, institutionalized application of risk analysis - to help and force decision-makers to consider the full consequences of their actions and to adjust policy choices accordingly ${ }^{192}$ - is not being served.

This situation is odd because the US military has a history of using economic analysis. Indeed it was the US military that brought concepts of systems analysis into government and helped them spread to other agencies. "When [Secretary of Defense Robert] McNamara assumed responsibility, he initiated the 'dispassionate' studies” for decision-making, whereas previously decisions had been made by more "intuitive” selection, writes Donald Smalter. "This was accomplished through a detailed analysis of alternatives by a section called the Systems Analysis group.”" McNamara created the high level office of Deputy Assistant Secretary for Systems Analysis (later the office of Program Analysis); the office was charged with making "costeffectiveness studies of major strategic and weapons systems alternatives." 194 McNamara's quantitative approach was exported to other sectors: "In 1961 the Defense Department, under a new Secretary of Defense, Robert McNamara, began a major management revolution... In August, 1965, President Lyndon Johnson announced his plans to develop comparable management systems in other executive departments,” noted Paul Hammond in 1968. ${ }^{195}$ Outside experts such as Albert Wohlstetter at RAND, Herman Kahn at the Hudson Institute and Thomas Schelling at Harvard were urging the defense agencies to take a decision analytic approach to thinking through military strategy and scenarios (often based on qualitative judgment rather than only quantified calculations). There is also an extensive literature on Operations Research in the military, collected in the text by N. K. Jaiswal. ${ }^{196}$ He notes that military operations research dates back to World War II but was often kept classified. ${ }^{197}$ It is plausible that the advent of economic analysis of health and environmental regulations in the Nixon, Carter and Reagan administrations grew out of or built upon the use of these same methods in the Defense Department and related agencies. Now the national security system can and should borrow back these methods for application to counterterrorism.

As the US undertakes a long war on terrorism, and especially as it employs precautionary strategies such as preventive war, the US government needs to adopt a much more systematic, institutionalized approach to ex ante and ex post review of counterterrorism measures. It needs to establish some form of rigorous White House oversight that will go beyond a narrow focus on the target risk of immediate concern to a proponent agency, toward a full portfolio analysis of target risk reduction benefits, costs, ancillary benefits and countervailing risks. Similarly, the UN Security Council needs such an institutional mechanism for its own decisions on preventive war, implementing the criteria set for the by the UN High-Level Panel ${ }^{198}$ - in particular, balancing the consequences of intervention.

The particular institutional home for such review in the US government could be the National Security Council (NSC), which already oversees the Defense and Intelligence agencies. At its 
best, the NSC helps the president think through problems and options, and highlights scenarios that include both intended and unintended consequences. ${ }^{199}$ It could also be the President's Homeland Security Advisory Council (PHSAC) noted above. Or it could be OMB/OIRA, which already reviews RIAs for Homeland Security regulations, but which may lack expertise on military strategy choices. Or the newly created Director of National Intelligence could undertake this task. To combine expertise, the NSC, PHSAC and OMB/OIRA could form a joint task group to set criteria for national security risk analyses and to review such analyses accompanying proposed actions submitted by agencies. The Defense Economic Analysis Council could be expanded and empowered to perform this role, at least for the Defense Department. Counterpart offices could play this role in other national governments. At the UN Security Council, a special expert staff could be created to undertake risk analyses.

Such reviews need not all be made public, though transparency would be a helpful tonic to sensible analysis. Nor need they be subject to judicial review, just as OIRA reviews are not.

A caveat to the foregoing: It may be that such analytic review of precautionary counterterrorism measures, including military actions, is already conducted, but that it remains classified and invisible to the public. This prospect seems doubtful given the lack of any such analysis reported by the 9/11 Commission, the Commission on Intelligence Capabilities Regarding WMD and other investigative panels that had access to classified documents. But if it does occur, then our suggestion is that it needs to be more searching and systematic to take account of the array of costs and countervailing risks identified above. Also, some greater degree of public transparency would both encourage greater rigor in the analyses and build public confidence in the decisions based on such analysis.

A second caveat: We make no claim that the results of such analysis should strictly dictate decisions. Systematic analysis should be a tool for improved decision-making, not a rigid constraint. Sometimes decisive action will have to be taken very quickly, in which case the analysis may have to be truncated; but inculcating the cognitive framework of full portfolio consequences analysis can still helpfully inform the rapid decision. Particularly in dealing with adversaries who behave strategically, an initial analysis of consequences cannot bind the government, because such a rule would in turn embolden a rogue state or terrorist actor to exploit the analysis by attacking. This would raise the probability of attack above the analysts' forecast and in effect engage in purposive moral hazard. An insightful analysis would account for just this kind of strategic response; it would envision scenarios in which the analysis itself influences the adversary. The key point is that counterterrorism decisions will be improved by thinking through the consequences.

\section{Conclusion}

Events are still unfolding, so we must wait to evaluate the ultimate ex post consequences of present counterterrorism policies. It will take years to tell whether the war in Iraq will actually reduce or increase the risk of terrorist attacks on the US, or have other impacts. The absence of a clear counterfactual scenario (what would have happened otherwise) may make it very difficult to say. When asked to appraise the French Revolution, Choe En Lai is said to have answered 
"it's too soon to tell." Full portfolio analyses of the consequences of counterterrorism measures should not wait indefinitely, nor should they be neglected, nor should they constitute a one-time exercise. Repeated analysis of consequences, before, during and after a policy is implemented, will be essential to deciding, learning, updating and adaptive improvement. And, of course, such analyses must compare alternative options for reducing the risk of terrorism, including precaution (preventive war), civil defense (target hardening and decentralization), undermining terrorist groups by impeding financing and recruitment (including via competing carrots), and other alternatives. $^{200}$ Here we have only proposed an analytic framework and institutional mechanism for making such comparative evaluations in the future.

The risk of terrorist attacks is sufficiently serious (even if low probability) that it may warrant precaution. But precautionary measures may turn out to increase, rather than decrease, the risk, such as by fostering blow-back, increased recruitment of terrorists, theft of WMD, displacement to softer targets and impairment of US military capabilities. Risk-superior solutions are urgently needed to reduce these multiple risks in concert.

Unintended consequences are not always unforeseeable. Precaution driven by overstated risk assessments and fear of dreaded risks will not yield sound policies. Sensible ex ante analysis can identify foreseeable but unintended consequences. Many of the new risks introduced by the war were foreseeable, at least as plausible scenarios. It was foreseeable that WMD might be dispersed rather than destroyed. It was foreseeable that the attack and occupation would be perceived as humiliating to Muslims, rather than as liberating, and that the campaign would benefit Al Qaeda and expand its ranks. It was foreseeable that the risk posed by Hussein would be reduced, but also that it would be transformed into a new risk posed by non-state actors, or by other rogue states now arming themselves. It was foreseeable that allowing interrogators to apply forms of coercive pressure could lead to disclosures of humiliating tactics that would only accelerate terrorists' recruiting. It was foreseeable that additional new risks could be introduced by setting a precedent for unilateral preventive war without Security Council approval.

Yet there does not seem to have been a systematic analysis of these benefits, costs and risks before the decision to engage in preventive war. More generally, there does not appear to be an institutional process for ex ante or ex post review of the expected consequences of proposed counterterrorism measures. Such a process should be established in each government or intergovernmental body taking important counterterrorism decisions. The shift to precaution in the US National Security Strategy, and in the US and UK invasion of Iraq, coupled with the crucial imperative to succeed in the war on terrorism by actually reducing overall risk, makes such analysis urgent and indispensable. The point here is not that the war in Iraq was a clear mistake - though, viewed ex post, it appears to have yielded a minimal reduction in target risk, unclear ancillary benefits, significant costs and significant countervailing risks (including military and civilian lives lost, increased terrorist recruiting, neglect of other risks of WMD and other rogue states, impaired US military capabilities, and potential loss of WMD from Iraq). The point here is larger: that counterterrorism, and especially precautionary counterterrorism, should draw valuable insights from risk analysis and, like other risk management interventions, should be preceded by (and later appraised using) a serious, systematic analysis of the full portfolio of expected impacts. This process should be established in appropriate institutional mechanisms. 
Full portfolio risk analysis can be a powerful counterweight to mission-driven agencies, passion for precaution, neglect of unintended consequences and "groupthink.” Benjamin Franklin advised a careful weighing of the pros and cons before making an important decision. He counseled that decisions tend to err "chiefly because while we have them under Consideration, all the Reasons pro and con are not present to the Mind at the same time ... yet, when each is thus considered, separately and comparatively, and the whole lies before me, I think I can judge better, and am less liable to make a rash Step." 201 Adam Smith wrote that "science is the great antidote to the poison of enthusiasm and superstition,"202 by which he meant that reasoned analysis overcomes ideology and zeal. Barbara Tuchman argued that the primary cause of military folly is the neglect of reason. ${ }^{203}$ Systematic analysis of the consequences of national security strategy can be the antidote to passionate haste and counterproductive folly. There is no patriotic glory in senseless pursuit of self-defeating strategies. Self-defense is not aided by firing hastily at the wrong targets. In the war on terrorism, it is the height of patriotism to insist that, before it acts, the government think things through. 


\section{ENDNOTES}

\footnotetext{
${ }^{1}$ Bush, G. W. (2002, September 17). The national security strategy of the United States of America: introduction and part V. <http://www.whitehouse.gov/nsc/nss.html> (cited 1 March 2003).

${ }^{2}$ For useful discussions, see Raffensperger, C. and Tickner, J. (ed.) (1999) Protecting Public Health and the Environment: Implementing the Precautionary Principle, Washington DC: Island Press; Sandin, P. (1999) Dimensions of the precautionary principle, Human \& Ecological Risk Assessment 5, 889; Wiener, J. B. (2005) Precaution, in J. Brunée, D. Bodansky and E. Hey (eds) The Oxford Handbook of International Environmental Law, Oxford: Oxford University Press, forthcoming; Wiener, J. B. and Rogers, M. D. (2002) Comparing precaution in the US and Europe, Journal of Risk Research 5, 317-349; and the symposium issues in the Journal of Risk Research Volumes 4 and 5 (2001 and 2002).
}

${ }^{3}$ For example, Rio declaration on environment and development (1992) 31 I.L.M. 876; Boehmer-Christiansen, S. (1994) The precautionary principle in Germany - enabling government, in T. O’Riordan and J. Cameron (eds) Interpreting the Precautionary Principle, pp.33. London: Cameron and May; Sandin (1999) Dimensions of the Precautionary Principle, cited above in note 2; Frequently asked questions. The Science and Environmental Health Network (SEHN). <http://www.sehn.org/ppfaqs.html> (cited 1 March 2003); Wiener and Rogers (2002) Comparing precaution in the US and Europe, cited above in note 2.

${ }^{4}$ Rio declaration: principle 15 (1992), cited above in note 3.

${ }^{5}$ European Environment Agency (EEA) (2002) Late lessons from early warnings.

${ }^{6}$ Bush (2002) The national security strategy of the United States, cited above in note 1.

${ }^{7}$ Lord Butler et al. (2004, July 14). Review of intelligence on WMD. The Butler Report.

$<$ http://www.butlerreview.org.uk>.

${ }^{8}$ Wiener and Rogers (2002) Comparing precaution in the US and Europe, cited above in note 2.

${ }^{9}$ Cirincione, J., Matthews, J. T., Perkovich, G., and Orton, A. (2004). WMD in Iraq: evidence and implications. Carnegie Institute for International Peace. $<$ http://www.carnegieendowment.org/files/Iraq3FullText.pdf>.

${ }^{10}$ Wiener and Rogers (2002) Comparing precaution in the US and Europe, cited above in note 2.

${ }^{11}$ Wiener and Rogers (2002) Comparing precaution in the US and Europe, cited above in note 2; Sandin (1999) Dimensions of the precautionary principle, cited above in note 2.

${ }^{12}$ Rio declaration (1992): Principle 15, cited above in note 3.

${ }^{13}$ Sanderson, H. and Peterson, S. (2001) Power analysis as a reflexive scientific tool for interpretation and implementation of the precautionary principle in the European Union, Environmental Science \& Pollution Research 8, 1-6. 
${ }^{14}$ Bush, G. W. (2002, October 7). Speech in Cincinnati. Cincinnati, Ohio.

${ }^{15}$ Bush (2002) The national security strategy of the United States, cited above in note 1.

${ }^{16}$ Bush, G. W. (2002 June 1). Remarks by the President at the 2002 graduation exercise of the United States Military Academy. West Point, New York. <http://www.whitehouse.gov/news/releases/2002/06/20020601-3.html> (cited 1 March 2003).

${ }^{17}$ Wallstrom M. (2002, April 25). US and EU environmental policies: converging or diverging? [Speech to the European Institute.]

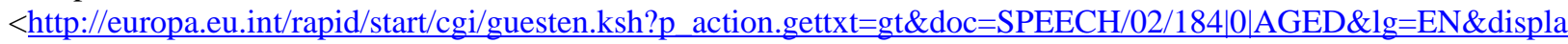
y> (cited 4 March2003).

${ }^{18}$ SEHN (2002), cited above in note 3.

${ }^{19}$ Gore, A. (1992) Earth in the Balance, Boston: Houghton Mifflin Company.

${ }^{20}$ Loewenberg, A. (2003 May 19). Precaution is for Europeans. The New York Times, 4.14.

${ }^{21}$ Murphy, R. (2003 February 9). Cross-country checkup, CBC Radio One.

<http://www.cbc.ca/checkup/archive/2003/intro030209.html $>$.

${ }^{22}$ Powell, C. (2003 March 7). Remarks to the United Nations Security Council.

<http://www.un.int/usa/03clp0307.htm>.

${ }^{23}$ Fleischer, A. (2002 December 5). Press briefing by Ari Fliescher, Press Secretary, the White House. <http://www.iraqwatch.org/government/US/HW/wh-fleischer-120502.htm>.

${ }^{24}$ Warner, M. (2002 December 19). The news hour with Jim Lehrer [Interview of Madeleine Albright], PBS. < $\underline{\text { http://www.pbs.org/newshour/bb/middle_east/july-dec02/iraq_12-19.html>. }}$

${ }^{25}$ Raffensperger and Tickner (1999) Protecting public health and the environment, 345-6, cited above in note 2.

${ }^{26}$ Runciman, D. (2004, April 1). The precautionary principle, London Review of Books 26(7).

$<$ http://www.lrb.co.uk/v26/n07/runc01_html $>$.

${ }^{27}$ Select Committee on Intelligence (2004 July 7). Report on the US intelligence community’s prewar intelligence assessments on Iraq. US Senate: Author. < $\underline{\text { http://intelligence.senate.gov/iraqreport2.pdf>. }}$

${ }^{28}$ Fischer, J. (2002 September 14). Address at the Fifty-seventh Session of the United Nations General Assembly. New York, NY. <http://www.auswaertiges-amt.de/www/en/aussenpolitik/index_html> (cited 6 March 2003).

${ }^{29}$ Duelfer, C. (2004 September 30). Comprehensive report of the special advisor to the DCI on Iraq's WMD. < $\underline{\text { http://www.cia.gov/cia/reports/iraq_wmd_2004/>. }}$

${ }^{30}$ Krugman, P. (2003 June 10). Who’s accountable. The New York Times, A27.

${ }^{31}$ Wildavsky, A. (1995) But Is It True? Cambridge: Harvard University Press.

${ }^{32}$ Blix, H. (2003 September 22). Blix: US led us astray on Iraq, Kathimerini English Edition [Greece’s international English language newspaper].

<http://www.ekathimerini.com/4dcgi/_w_articles_politics_100014_22/09/2003_34326 >. 
${ }^{33}$ Hulse, C. and Sanger, D. E. (2003 September 29). New criticism on prewar use of intelligence,The New York Times, A1. (Quotes letter from Representatives J. Porter Goss, R-FL, and Jane Harman, D-CA.)

34 The failure to find Iraqi weapons (2003 September 26). The New York Times, A24 [editorial].

${ }^{35}$ Lewis, A. (2001 March 31). The feelings of a coup, The New York Times, A15.

${ }^{36}$ Loewenberg (2003) Precaution is for Europeans, cited above in note 20.

${ }^{37}$ Runciman (2004) The precautionary principle, cited above in note 26.

${ }^{38}$ Duelfer (2004) Comprehensive report on Iraq's WMD, cited above in note 30; Commission on the Intelligence Capabilities of the US Regarding WMD (2005 March 31). Report to the President of the United States.

$<$ www.wmd.gov> . (Commission co-chaired by Judge Laurence Silberman and Senator Charles Robb, D-VA.)

${ }^{39}$ Runciman (2004) The precautionary principle, cited above in note 26; Weeks, Lieutenant Colonel M. (2003) Cost-benefit economics: enhancing national security and air and space power, Air \& Space Power Journal. $<$ http://www.airpower.maxwell.af.mil/airchronicles/apj/apj03/fal03/weeks.html>.

${ }^{40}$ Olivier Godard argues that the Iraq War does not correspond to more sophisticated versions of the Precautionary Principle. See Godard, O. (2003 May 26). Revisiting the precautionary principle under the light of recent French and international events. [Keynote address at the ALLIANCE Workshop: Revisiting global public policies for sustainable development - a transatlantic dialogue.] Cahiers de la chaire développement durable X-EDF, 2003-004, pp.5-7. < http://ceco.polytechnique.fr/CDD/PDF/2003-005.pdf >. Godard's argument is that more sophisticated version of the Precautionary Principle, such as the European Commission's Feb. 2000 Communication on the Precautionary Principle, redefine the Precautionary Principle as a form of decision analysis requiring scientific risk analysis, proportionality, provisionality, and benefit-cost analysis - in contrast to more aggressive versions of the Precautionary Principle that reject such analysis. What we show is that the war in Iraq and the US National Security Strategy do correspond to the language and logic of the more aggressive versions of the Precautionary Principle that lack such decision analytic features. That is why we call in this paper for the application of such decision analysis to improve precautionary counterterrorism policymaking.

${ }^{41}$ Sanderson and Peterson (2001) Power analysis of the precautionary principle in the European Union, cited above in note 13; EEA (2002) Late lessons from early warnings, cited above in note 5.

42 Jervis, R. (2003) Understanding the Bush doctrine, Political Science Quarterly 118: 365-388.

${ }^{43}$ Ackerman, D. M. (2003 April 11) International law and the preemptive use of force against Iraq,Congressional Research Service (CRS) Report RS21314.

${ }^{44}$ Ackerman (2003) International law and the preemptive use of force against Iraq, 2, cited above in note 43.

${ }^{45}$ Ackerman (2003) International law and the preemptive use of force against Iraq, 2, cited above in note 43.

${ }^{46}$ Walzer, M. (1977) Just and Unjust Wars: A Moral Argument with Historical Illustrations, pp.74-75. New York: Basic Books, Inc.

${ }^{47}$ Grimmett, R. F. (2003 April 11). US use of preemptive military force, Congressional Research Service (CRS) Report RS21311; Weeks (2003) Enhancing national security and air and space power, cited above in note 39.

${ }^{48}$ Ackerman (2003)International law and the preemptive use of force Against Iraq, 3-4, cited above in note 43.

${ }^{49}$ Ackerman (2003)International law and the preemptive use of force Against Iraq, 6, cited above in note 43. 
${ }^{50}$ Ackerman (2003)International law and the preemptive use of force Against Iraq, 6, cited above in note 43.

${ }^{51}$ Feinstein, L. and Slaughter, A. (2004) A duty to prevent, Foreign Affairs 83(1) : 136-151.

${ }^{52}$ Feinstein and Slaughter (2004) A duty to prevent, cited above in note 51.

${ }^{53}$ Yoo, J. (2004) Using force, University of Chicago Law Review 71: 729-797.

54 Jordan A. and O’Riordan, T. (1999) The precautionary principle in contemporary environmental policy and politics, in Raffensperger and Tickner (1999) Protecting Public Health and the Environment, cited above in note 2.

55 Pearce, D. (1994) The precautionary principle in economic analysis, in T. O'Riordan and J. Cameron (eds) Interpreting the precautionary principle, London: Cameron and May; European Commission (2000)

Communication from the commission on the precautionary principle (COM 1). Brussels: Author. <http://europa.eu.int/comm/dgs/health_consumer/library/pub/pub07_en.pdf>; Graham, J. D. and Wiener, J. B. (1995) Risk vs. Risk: Tradeoffs in Protecting Health and the Environment, Cambridge: Harvard University Press; Keeney, R. L. and von Winterfeldt, D. (2001) Appraising the precautionary principle - a decision analysis perspective, Journal of Risk Research 4: 191; Michael Dekay et al. (2002) Risk-based decision analysis in support of precautionary policies, Journal of Risk Research 5: 391; Stewart, R. B. (2002) Environmental regulatory decisionmaking under uncertainty, Research in Law and Economics 20: 71-152; Gollier, C. and Treich, N. (2003) Decision making under uncertainty: the economics of the precautionary principle, Journal of Risk \& Uncertainty 27: 77; Farrow, S. (2004) Using risk-assessment, best-cost analysis, and real options to implement a precautionary principle, Risk Analysis 24, 727; Posner, R. A. (2004) Catastrophe: Risk and Response, Oxford: Oxford University Press.

${ }^{56}$ High-Level Panel on Threats, Challenges and Change (2004 December 2). A more secure world: our shared responsibility. [Report to the Secretary General, United Nations General Assembly, 59 ${ }^{\text {th }}$ Session, Agenda Item 55. ] $<$ http://www.un.org/secureworld/report.pdf $>$.

${ }^{57}$ High-Level Panel on Threats, Challenges and Change (2004 December 2). A more secure world: our shared responsibility, cited above in note 56.

58 Annan, K. (2004 December 2). Courage to fulfil our responsibilities, The Economist.

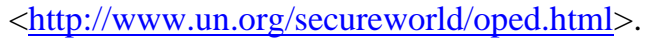

59 Jervis (2003) Understanding the Bush doctrine, cited above in note 42.

${ }^{60}$ Malkin, M. (2004) In Defense of Internment, Regnery Publishing.

${ }^{61}$ Weeks (2003) Enhancing national security and air and space power, cited above in note 39.

${ }^{62}$ Goldenberg, S. (2005 April 29). Ex-CIA Chief eats humble pie, The Guardian. <http://www.guardian.co.uk/Iraq/Story/0,2763,1472826,00.html $>$.

${ }^{63}$ Butler et al. (2004) Review of intelligence on WMD, cited above in note 7.

${ }^{64}$ Feaver, P. (2004 January 28). The fog of WMD, The Washington Post, A21.

${ }^{65}$ Pillar, P. (2004 June 4). A scapegoat is not a solution, The New York Times.

${ }^{66}$ Pillar (2004) A scapegoat is not a solution,, cited above in note 65. 
${ }^{67}$ National Commission on Terrorist Attacks upon the United States (2004) The 9/11 Commission Report: Final Report of the National Commission on Terrorist Attacks upon the United States Authorized Edition, New York: W. W. Norton.

${ }^{68}$ The Select Committee on Intelligence, for instance, found after 9/11 that the CIA presumed that Iraq had WMD but discounted evidence to the contrary. See Select Committee on Intelligence (2004) Report on the US intelligence community's prewar intelligence assessments on Iraq, 20, cited above in note 27.

${ }^{69}$ Butler et al. (2004) Review of intelligence on WMD, cited above in note 7.

${ }^{70}$ Select Committee on Intelligence (2004) Report on the US intelligence community's prewar intelligence assessments on Iraq, 14, cited above in note 27.

${ }^{71}$ Select Committee on Intelligence (2004) Report on the US intelligence community's prewar intelligence assessments on Iraq, 16-21, cited above in note 27.

${ }^{72}$ Select Committee on Intelligence (2004) Report on the US intelligence community's prewar intelligence assessments on Iraq, 25, cited above in note 27.

${ }^{73}$ Commission on the Intelligence Capabilities of the US Regarding WMD (2005) Report to the President of the United States.

${ }^{74}$ Shane, S. and Sanger, D. E. (2005 April 1) The intelligence critique: the report: Bush panel finds big flaws remain in US spy efforts, The New York Times, A1.

${ }^{75}$ Shane and Sanger (2005) Bush panel finds big flaws remain in US spy efforts, cited above in note 74.

${ }^{76}$ Select Committee on Intelligence (2004) Report on the US intelligence community's prewar intelligence assessments on Iraq, 34, cited above in note 27.

${ }^{77}$ Shane and Sanger (2005) Bush panel finds big flaws remain in US spy efforts, cited above in note 74.

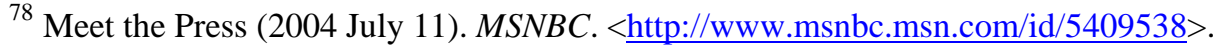

${ }^{79}$ Shane and Sanger (2005) Bush panel finds big flaws remain in US spy efforts, cited above in note 74.

${ }^{80}$ Meet the Press (2005 April 10). MSNBC. $<$ http://www.msnbc.msn.com/id/7452510>.

${ }^{81}$ Butler et al. (2004) Review of intelligence on WMD, 82, cited above in note 7.

${ }^{82}$ Butler et al. (2004) Review of intelligence on WMD, 16, cited above in note 7.

${ }^{83}$ Butler et al. (2004) Review of intelligence on WMD, 81, cited above in note 7.

${ }^{84}$ Butler et al. (2004) Review of intelligence on WMD, 82, cited above in note 7.

${ }^{85}$ Butler et al. (2004) Review of intelligence on WMD, 80, cited above in note 7.

${ }^{86}$ Butler et al. (2004) Review of intelligence on WMD, 125-127, cited above in note 7. 
${ }^{87}$ Brom, S. (2003) The war in Iraq: an intelligence failure, Jaffe Center's Strategic Assessment 6(3). $<$ www.tau.ac.il $>$.

${ }^{88}$ Stern, J. (1999) The Ultimate Terrorists, Cambridge: Harvard University Press.

${ }^{89}$ Jehl, D. (2004 September 22). CIA review is critical of prewar analysis, The New York Times, A18.

${ }^{90}$ Kahneman, D., Slovic, P. and Tversky, A. (1982) Judgment Under Uncertainty: Heuristics and Biases, Cambridge: Cambridge University Press.

${ }^{91}$ Posner (2004) Catastrophe: risk and response, cited above in note 55; Dana, D. (2003) A behavioral economic defense of the precautionary principle, Northwestern University Law Review 97 : 1315.

${ }^{92}$ Slovic, P. (2000) The Perception of Risk, London: Earthscan; Slovic, P. and Weber, E. (2003) Perception of risk posed by extreme events. Unpublished paper, Columbia University Center for Hazards and Risk Research. $<$ www.ldeo.columbia.edu/chrr/documents/meetings/roundtable/white_papers/slovic_wp.pdf $>$. For an argument that the availability heuristic leads people to fear the recurrence of terrorism without regard to the actual probability of attacks, see Sunstein, C. R. (2003) Terrorism and probability neglect, Journal of Risk and Uncertainty 26(2-3): 121136.

${ }^{93}$ Pillar, P. (2004) Counterterrorism after Al Qaeda, The Washington Quarterly 27(3): 101-113.

${ }^{94}$ Pillar (2004) A scapegoat is not a solution, cited above in note 65.

${ }^{95}$ Sunstein, C. R. and Kuran, T. (1999) Availability cascades and risk regulation, Stanford Law Review 51: 683-768.

${ }^{96}$ Andrews, R. N. L. (1999) Managing the Environment, Managing Ourselves: A History of American Environmental Policy, New Haven: Yale University Press; Percival, R. (1998) Environmental legislation and the problem of collective action, Duke Environmental Law \& Policy Forum 9: 9-28.

${ }^{97}$ Posner, R. A. (2004 August 29). [Review of the book The 9/11 Report]. The New York Times Book Review, 9.

${ }^{98}$ Chalk, P. (1996) West European Terrorism and Counter-Terrorism, New York: St. Martin’s Press, 99.

${ }^{99}$ Butler et al. (2004) Review of intelligence on WMD, cited above in note 7.

${ }^{100}$ Stern, J. (2002) Dreaded risks and the control of biological weapons, International Security 27(3): 89-123; Slovic, P. (1987) Perception of risk, Science 236: 280-285; Sunstein (2003) Terrorism and probability neglect, cited above in note 92.

${ }^{101}$ Stern (1999) The Ultimate Terrorists; Stern, J. (2003 December 18). When bombers are women, The Washington Post.

${ }^{102}$ Slovic (1987) Perception of risk, cited above in note 100; Sunstein (2003) Terrorism and probability neglect, cited above in note 92.

${ }^{103}$ Slovic (1987) Perception of risk, cited above in note 100; Sunstein, C. R. (2005) The Laws of Fear: Beyond the Precautionary Principle, Cambridge: Cambridge University Press.

${ }^{104}$ Nieman, S. (2002) Evil in Modern Thought, Princeton: Princeton University Press, pp. 284-85.

${ }^{105}$ Miller, W. I. (1997) The Anatomy of Disgust, Cambridge: Harvard University Press, 26. 
${ }^{106}$ Bentham, J. (1830) Principles of Legislation, Boston: Wells and Lilly, xviii, section 17.

${ }^{107}$ Peres-Rivas, M. (2001 September 16). Bush vows to rid the world of evil-doers, CNN. $<$ http://archives.cnn.com/2001/US/09/16/gen.bush.terrorism/>.

${ }^{108}$ Wiener, J. B. (2004) Precaution, risk and multiplicity. [Paper prepared for the Harvard Law School Conference on Environmental Law].

${ }^{109}$ Weeks (2003) Enhancing national security and air and space power, cited above in note 39. For an intriguing application of economic analysis to evaluate the consequences of several alternatives, comparing military measures to other counterterrorism strategies such as decentralizing potential targets, recruiting potential terrorists to other opportunities, and diffusing news media coverage of terrorist groups' claims, see Frey, B. (2004) Dealing with Terrorism: Stick or Carrot? London: Edward Elgar.

${ }^{110}$ The 9/11 Commission Report (2004), pp. 391, cited above in note 67.

${ }^{111}$ The 9/11 Commission Report (2004), pp. 374-75, cited above in note 67.

${ }^{112}$ Weeks (2003) Enhancing national security and air and space power, cited above in note 39.

${ }^{113}$ Sunstein, C. R. (2001) Cognition and cost-benefit analysis, in M. Adler and E. Posner (eds) Cost-Benefit Analysis, Chicago: Univeristy of Chicago Press Journals. Also in Journal of Legal Studies 29 (2000): 1059-1104.

${ }^{114}$ Wiener, J. B. (1998) Managing the iatrogenic risks of risk management, Risk: Health Safety \& Environment 9: 49-82; Rascoff, S. and Revesz, R. L. The biases of risk tradeoff analysis: towards parity in regulatory policy, University of Chicago Law Review 89: 1763; Weiner (2004) Precaution, risk and multiplicity, cited above in note 108.

${ }^{115}$ Posner (2004) Catastrophe: risk and response, cited above in note 55.

${ }^{116}$ Pillar (2004) Counterterrorism after Al Qaeda, cited above in note 93.

${ }^{117}$ Duelfer (2004) Comprehensive report of the special advisor to the DCI on Iraq's WMD, cited above in note 30.

${ }^{118}$ Duelfer (2004) Comprehensive report of the special advisor to the DCI on Iraq's WMD, cited above in note 30.

${ }^{119}$ Davis, S. J., Murphy, K. M. and Topel, R. H. (2003 March 20). War in Iraq versus containment: weighing the costs. Unpublished paper.

${ }^{120}$ Graham and Wiener (1995) Risk vs. Risk: Tradeoffs in Protecting Health and the Environment, cited above in note 55; Rascoff and Revesz (2002) The biases of risk tradeoff analysis; Weiner (2004) Precaution, risk and multiplicity, cited above in note 114 .

${ }^{121}$ Davis, Murphy and Topel (2003) War in Iraq versus containment, cited above in note 119.

${ }^{122}$ Ignatieff, M. (2005 June 26) Who are Americans to think that freedom is theirs to spread? The New York Times Sunday Magazine, $42-47$.

${ }^{123}$ Jervis (2003) Understanding the Bush doctrine, 367 cited above in note 42.

124 Jervis (2003) Understanding the Bush doctrine, 367 cited above in note 42. 
${ }^{125}$ Jervis (2003) Understanding the Bush doctrine, 386 cited above in note 42.

${ }^{126}$ Ignatieff (2005) Who are Americans to think that freedom is theirs to spread?, 44, cited above in note 122.

${ }^{127}$ Zakaria, F. (2005 June 27) How to change ugly regimes, Newsweek, 31.

${ }^{128}$ Scheuer, M. (2004) Imperial Hubris: Why the West Is Losing the War on Terror, Potomac Books; Pape, R. A. (2005) Dying to Win: The Strategic Logic of Suicide Terrorism, New York: Random House.

${ }^{129}$ Abadie, A. (2004) Poverty, political freedom and the roots of terrorism, NBER Working Paper 10859. $<$ http://www.nber.org/papers/w10859>; Ignatieff (2005) Who are Americans to think that freedom is theirs to spread?, 44 - 45, cited above in note 122.

${ }^{130}$ Wortzel, L. M. (March 17) Combating weapons of mass destruction. [Testimony delivered to the Armed Services Committee, US House of Representatives.].

${ }^{131}$ Schmitt, G. (2004 May 30) Shooting first, Los Angeles Times.

${ }^{132}$ The 9/11 Commission Report (2004), 361, cited above in note 67.

${ }^{133}$ Nordhaus, W. (2002) The economic consequences of a war with Iraq, in War with Iraq: Costs, Consequences and Alternatives, American Academy of Arts \& Sciences.

<www.econ.yale.edu/ nordhaus/homepage/homepage.htm>.

${ }^{134}$ Nordhaus (2002) The economic consequences of a war with Iraq, 77, cited above in note 133.

135 Nordhaus (2002) The economic consequences of a war with Iraq, 73 and fig. 1, cited above in note 133.

${ }^{136}$ Nordhaus (2002) The economic consequences of a war with Iraq, 51-52, 78-80, cited above in note 133.

${ }^{137}$ Davis, Murphy and Topel (2003) War in Iraq versus containment,, cited above in note 119.

${ }^{138}$ Wallsten, S. and Kosec, K. (2005) The Economic costs of the war in Iraq, AEI-Brookings Joint Center for Regulatory Studies Working Paper 05-19. <http://www.aei-brookings.org/admin/authorpdfs/page.php?id=1199>; Wallsten and Kosec also provide an interactive estimator on the cost of the war, available at $<$ http.//aeibrookings.org/iraqcosts/>.

${ }^{139}$ Wiener (1998) Managing the iatrogenic risks of risk management, cited above in note 114; Stern, J. (2003) The protean enemy, Foreign Affairs 82(4): 27-40.

${ }^{140}$ Graham and Wiener (1995) Risk vs. Risk: Tradeoffs in Protecting Health and the Environment, cited above in note 55 .

${ }^{141}$ Graham and Wiener (1995) Risk vs. Risk: Tradeoffs in Protecting Health and the Environment, cited above in note 55 .

${ }^{142}$ Stern (2002) Dreaded Risks and the Control of Biological Weapons, cited above in note 100.

${ }^{143}$ Tuchman, B. W. (1984) The March of Folly: From Troy to Vietnam, New York: Ballantine Books.

${ }^{144}$ Keeney, R. (2001 December 20-22). Countering terrorism: the clash of values, ORMS Today 28(6). 
${ }^{145}$ Stern (2003) The protean enemy, cited above in note 139.

${ }^{146}$ Lakdawala D. and Zanjani, G. (2002 July 17). Insurance, self-protection and the economics of terrorism. Unpublished paper; Keohane, N. and Zeckhauser, R. (2002 October 3). The ecology of terror defense. Unpublished

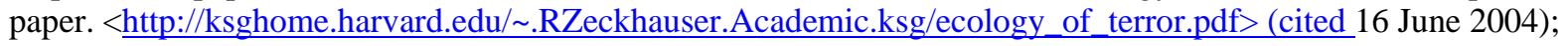
Clotfelter, C. T. (1978) Private security and the public safety, Journal of UrbanEconomics 5 : 388-402.

147 Johnson, C. (2004) Blowback: The Costs and Consequences of American Empire, $2^{\text {nd }}$ ed, Owl Books.

${ }^{148}$ Stern (2003) When bombers are women, cited above in note 101.

${ }^{149}$ Graham and Wiener (1995) Risk vs. Risk: Tradeoffs in Protecting Health and the Environment, cited above in note 55 .

${ }^{150}$ Weiner (2004) Precaution, risk and multiplicity, cited above in note 108.

${ }^{151}$ Boehmer-Christiansen (1994) The precautionary principle in Germany, cited above in note 3.

${ }^{152}$ Wiener, J. B. (2002) Precaution in a multirisk world, in D. D. Paustenbach (ed) Human and Ecological Risk Assessment: Theory and Practice, John Wiley \& Sons.

${ }^{153}$ Herold, M. A dossier on civilian victims of United States’ aerial bombing of Afghanistan: a comprehensive accounting. $<$ http://pubpages.unh.edu/ mwherold/>.

${ }^{154}$ Les Roberts et al. (2004 October 29). Mortality before and after the 2003 invasion of Iraq: cluster sample survey, The Lancet 364: 1857-1864.

<http://www.thelancet.com/journals/lancet/article/PIIS0140673604174412/fulltext.htm>.

${ }^{155}$ Knickerboacker, B. (2004 March 31) Who counts the civilian casualties? Christian Science Monitor.

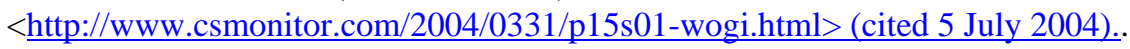

${ }^{156}$ Pillar (2004) Counterterrorism after Al Qaeda, cited above in note 93.

${ }^{157}$ Pillar (2004) Counterterrorism after Al Qaeda, cited above in note 93.

${ }^{158}$ Scheuer (2004) Imperial Hubris, cited above in note 128.

${ }^{159}$ Fallows, J. (2004) Bush’s lost year, The Atlantic Monthly, 68-84.

${ }^{160}$ Clarke, R. (2004) Against All Enemies, Free Press.

${ }^{161}$ Cirincione et al. (2004) WMD in Iraq: evidence and implications, cited above in note 9.

162 Adams, A. (2004 September 21). Bush described as al-Qaeda’s ‘best recruiting sergeant’ by UK ambassador, Financial Times, 1.

${ }^{163}$ Cirincione et al. (2004) WMD in Iraq: evidence and implications, 58, cited above in note 9.

164 Tuchman (1984) The march of folly, cited above in note 143.

${ }^{165}$ Myre, G. (2005 February 18). Israel halts decades-old practice of demolishing militants' homes, The New York Times. 
${ }^{166}$ Hutchings, R. (2004) X + 9/11, Foreign Policy 143.

${ }^{167}$ Fanon, F. (1961) The Wretched of the Earth, New York: Grove Press.

${ }^{168}$ Buchanan, P. J. (2004) Where the Right Went Wrong, Thomas Dunne Books.

${ }^{169}$ Gore, A. (2004 May 29). Remarks. <http://www.moveonpac.org/goreremarks052604.html/> (cited 29 May 2004).

${ }^{170}$ Pillar (2004) Counterterrorism after Al Qaeda, cited above in note 93.

${ }^{171}$ Pape (2005) Dying to Win, cited above in note 128; Bloom, M. (2005) Dying to Kill: The Allure of Suicide Terror, New York: Columbia University Press.

${ }^{172}$ Fallows (2004) Bush's lost year, 72, cited above in note 159.

${ }^{173}$ Schmitt, E. (2005 March 4). Army officials voice concern over shortfall in recruitment, The New York Times, A1.

${ }^{174}$ Daalder, I. H., Lindsay, J. M. and Steinberg, J. B. (2002) The Bush national security strategy: an evaluation, The

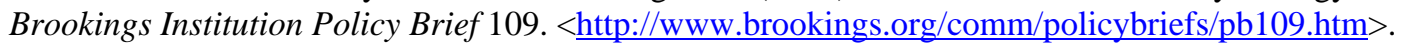

${ }^{175}$ Glanz, J., Broad, W. J. and Sanger, D. E. (2004 October 25). Tracking the weapons: huge cache of explosives vanished from site in Iraq, The New York Times.

${ }^{176}$ Cirincione et al. (2004) WMD in Iraq: evidence and implications, 58-59, cited above in note 9.

${ }^{177}$ Daalder, Lindsay and Steinberg (2002) The Bush national security strategy: an evaluation, cited above in note 174.

${ }^{178}$ Wiener (2002) Precaution in a multirisk world, cited above in note 152; Sunstein (2005) The Laws of Fear: Beyond the Precautionary Principle.

${ }^{179}$ Breyer, S. G. (1993) Breaking the Vicious Circle: Toward Effective Risk Regulation, Cambridge: Harvard University Press.

${ }^{180}$ Graham, J. D. (2001) Decision-analytic refinements of the precautionary principle, Journal of Risk Research 4: 127; Graham, J. D. (2004) [Remarks at the Inaugural Session of the International Risk Governance Council (IRGC).] Geneva.

${ }^{181}$ The war on terror: that not-winning feeling (2005 June 18). The Economist, 27.

${ }^{182}$ Weeks (2003) Enhancing national security and air and space power, cited above in note 39.

${ }^{183}$ Sunstein (2000) Cognition and cost-benefit analysis, cited above in note 113.

${ }^{184}$ The 9/11 Commission Report (2004), 374-75, cited above in note 67.

${ }^{185}$ Yoo (2004) Using force, 729, cited above in note 53.

${ }^{186}$ Weeks (2003) Enhancing national security and air and space power, cited above in note 39. 
${ }^{187}$ The war on terror: that not-winning feeling (2005) The Economist, cited above in note 181.

${ }^{188}$ Wiener, J. B. (2003) Whose precaution after all? A comment on the comparison and evolution of risk regulation systems, Duke Journal of Comparative and International Law 13: 207-262; Lofstedt, R. (2004) The swing of the regulatory pendulum in Europe, Journal of Risk \& Uncertainty 28: 237-260.

189 See, for example, Pearce (1994) The precautionary principle in economic analysis, cited above in note 55; European Commission (2004) Communication on the precautionary principle, cited above in note 55; Graham (2001) Decision-analytic refinements of the precautionary principle, cited above in note 178; Keeney and von Winterfeldt (2001) Appraising the precautionary principle, cited above in note 55; Dekay et al. (2002) Risk-based decision analysis in support of precautionary policies, cited above in note 55; Stewart (2002) Environmental regulatory decision-making under uncertainty, cited above in note 55; Gollier and Treich (2003) Decision making under uncertainty, cited above in note 55; Farrow (2004) Using risk-assessment, benefit-cost analysis and real options to implement a precautionary principle, cited above in note 55; Posner (2004) Catastrophe: risk and response, cited above in note 55.

${ }^{190}$ Fallows (2004) Bush’s lost year, 73, cited above in note 159.

${ }^{191}$ See $<$ www.whitehouse.gov/news/releases/2002/03/20020321-9.html $>$.

${ }^{192}$ Sunstein (2000) Cognition and cost-benefit analysis, cited above in note 113; Wiener (1998) Managing the iatrogenic risks of risk management, cited above in note 114.

193 Smalter, D. (1964) The influence of department of defense practices on corporate planning, Management Technology 115: 116.

${ }^{194}$ Smalter, D. (1964) The influence of department of defense practices on corporate planning, 117, cited above in note 193.

${ }^{195}$ Hammond, P. (1968) A functional analysis of defense department decision-making in the McNamara administration, American Political Science Review 62: 57.

196 Jaiswal, N. K. (1997) Military Operations Research: Quantitative Decision Making, Boston: Kluwer Academic Publishers.

197 Jaiswal (1997) Military Operations Research, ix, cited above in note 196.

${ }^{198}$ Annan (2004) Courage to fulfil our responsibilities, cited above in note 58.

${ }^{199}$ Rothkopf, D. J. (2005) Running the World: The Inside Story of the National Security Council and the Architects of American Power, Washington DC: Public Affairs.

${ }^{200}$ For a useful economic analysis of alternatives, see Frey (2004) Dealing with Terrorism: Stick or Carrot?, cited above in note 109. Frey concludes that military intervention and deterrence are likely to be less effective at reducing the risk of future terrorist attacks than are alternative strategies such as decentralizing targets and recruiting potential terrorists to other pursuits.

${ }^{201}$ Franklin, B. (1936) Letter to Joseph Priestley, in F. L. Mott and C. E. Jorgenson, Benjamin Franklin: Representative Selections, with Introduction, Bibliography and Notes, New York: American Book Company, 348349.

${ }^{202}$ Smith, A. (1776) An Inquiry into the Nature and Causes of the Wealth of Nations, Book V, Ch. I, Pt. 3, Art. 3. 
${ }^{203}$ Tuchman (1984) The march of folly, cited above in note 143. 